\title{
EFFECT OF NUTRIENT SOLUTION STRENGTH ON GROWTH AND YIELD OF GRAFTED AND NON-GRAFTED CUCUMBER GROWN HYDROPONICALLY IN GREENHOUSE
}

\author{
M.E.M. Ahmed ${ }^{(1)}$, S. A. Abdelhady ${ }^{(2)}$ and T.M.I. Kandeel ${ }^{(1)}$ and R.M. Mahdy ${ }^{(1)}$ \\ ${ }^{(1)}$ Hort. Dept., Faculty of Agric., Tanta Univ., Egypt. \\ (2) Hort. Dept., Faculty of Agric., Ain Shams Univ., Cairo, Egypt.
}

Received: Oct. 4, 2020

Accepted: Oct. 10,2020

\begin{abstract}
Growing cucumber through the grafted transplants has become extremely important to control the risk of consecutive cucumber cultivation in the greenhouses. The experiment was implemented in the experimental farm of Horticulture Dept., Faculty of Agriculture, Ain Shams University during the 2018 and 2019 growing seasons. Indeed there are no true estimates of the nutrient requirements of grafted cucumber plants under Egyptian conditions. Therefore, this study was conducted on the cucumber, cv. Barracuda F1hybrid, using either grafted and non-grafted transplants. The grafted transplants were prepared by grafting onto rootstock $6001 \mathrm{~F}$. Both grafted and non-grafted transplants were grown hydroponically in a greenhouse in pots filled with 7 $\mathrm{kg}$ of well-washed sand media. The plants were irrigated with nutrient solution at a strength of $70 \%, 80 \%, 90 \% 100 \%$, and $110 \%$ throughout the plants' life. The pots were irrigated daily till sand soil water content reaching the field capacity. The results till that growing grafted cucumber transplants improved all vegetative plant growth parameters in terms of fresh shoot weight, fresh root weight, dry shoot weight, dry root weight, dry leaves weight, stem length, stem diameter, the number of leaves, and leaf chlorophyll SPAD). The and yield as well as leaf nutrient elements content were also enhanced by grafted compared to non-grafted transplants. For the nutrient solution strength, the data evidenced that all assessed parameters recorded ascending values matching with nutrient solution strength increase. The highest values were got with $100 \%$ nutrient solution strength. At $110 \%$ nutrient solution strength most vegetative and yield parameters did not significantly different from $100 \%$ strength in grafted plants. But in non-grafted plants, most parameters tended to decline thus indicate the probability of salt stress. The results establish that there is no need to increase the concentration of the nutrient solution to face the increasing of grafted cucumber plant yield, where grafting on good rootstocks increases water and fertilizer use efficiency.
\end{abstract}

Key words: Cucumber; grafting; Yield; Fruit quality; Mineral composition; growth parameters

\section{INTRODUCTION}

Cucumber (Cucumis sativus L.) is a popular and economical vegetable crop grown in the greenhouses in the winterspring season in Egypt. Intensifying cucumber production in the greenhouses via consecutive cultivation or monoculture without applying a proper rotation leads to a higher loss through attacking pests and soil-borne diseases infection which could destroy the crop (Huang et al, 2002). To avoid the risk of monoculture, it is necessary for adopting disinfection or grafting practices (Bogoescu et. al. 2011). Thus the grafting plants became one of the optimal solutions, especially with stopping the usage of methyl bromide, for overcoming this phenomenon and increasing growth, yield, and quality (Bogoescui and 
Doltuiei, 2015; El- Kersh et al 2016). Otherwise many investigations on grafting refer that rootstock confers the scion more benefits through controlling the plant vital events of uptake, synthesis, and translocation of water, minerals, and plant hormones (Lee and Oda, 2003). Nawaz et al (2016) reviewed that rootstock donates scion numerous economic benefits as increasing leaves nutrient concentration, shoots biomass, yield, and fruit quality. Thereby plant optimal growth and uptake of water and nutrients depend on root-soil contact (Gregory et al 2013). Grafting cucurbits always implemented on strong and compatible rootstocks thence changing root architecture, increasing root-soil contact, increasing water and nutrients uptake, increasing photosynthesis, and finally reflected on plant growth, yield, and quality (Davis et al., 2008). In Egypt usage grafted transplants in cucumber cultivation in the greenhouse became a routine practice so it becomes necessary to define the proper fertilization rate for grafted cucumber plants particularly with scarce the researches on determining the fertilization requirements of grafted cucumber plants. This research will focus on the performance of grafted and non-grafted cucumber plants irrigated with different nutrient solution strengths under greenhouse conditions.

\section{MATERIALS AND METHODS}

Experimental site and plant material, treatments and growth conditions.

The experiment was implemented on cucumber (Cucumis sativus L.) at WinterSpring of 2018 and 2019 growing seasons in a $240 \mathrm{~m} 2 \quad\left(6 \mathrm{~m}^{*} 40 \mathrm{~m}\right)$ polyethylene greenhouse tube shape, located in the experimental farm of Hort. Dept., Agric. Faculty, Ain Shams University, Cairo Egypt. The plants were grown under natural temperature and light conditions of the greenhouse. The cucumber cultivar used in this experiment was Barracuda $F 1$ is produced by Seminis Vegetable Seeds Company, USA. The experiment involved 300 pots filled with $10 \mathrm{~kg}$ of well-washed sand and was planted with one transplant. Half of the used transplants were grafted onto the commercial rootstock 6001 F1 squash (Cucurbita maxima $\times$ Cucurbita moschata) produced by Nun hems Seed Company, USA, but the other half was without grafting. At the three leaves stage, the grafted and non-grafted transplants were transplanted into the pots on 10th February for the two growing seasons. The pots were arranged in 30 rows (10 pots within the row, 5 pots had grafted and 5 pots had non-grafted transplants), every 10 rows presentative as a replicate. Every two rows within each replicate were irrigated with a drip irrigation line using one nutrient solution strength of $70 \%, 80 \%, 90 \% 100 \%$, and $110 \%$. The space between pots within the row was $0.5 \mathrm{~m}$ and the distance between the centers of each adjacent two rows was $1.2 \mathrm{~m}$. Plants were grown vertically with pruning the lateral branches. The nutrient solution in full strength (100\%) involved nutrients concentration as described in Table 1. All treatments received the daily optimal irrigation level (to reach the field capacity) over the growing season. All agronomic practices (pruning, trailing, and pest and disease treatments) were done as recommended by the Egyptian agriculture ministry for greenhouse cucumber production.

\section{Experimental design and data analysis}

The experiment involved 10 treatments which were 2 transplants types (grafted and non-grafted) combined with 5 nutrient solution strengths $(70 \%$, $80 \%, 90 \% 100 \%$, and $110 \%)$ were 
distributed in a randomized complete

replicated three times.

block design. Each treatment was

Table 1: Concentrations of nutrients with cooper solution.

\begin{tabular}{|c|c|c|}
\hline Element & Cod & Concentration in ppm \\
\hline Nitrogen & N & 200 \\
\hline Phosphorous & P & 60 \\
\hline Potassium & $\mathrm{K}$ & 300 \\
\hline Calcium & $\mathrm{Ca}$ & 170 \\
\hline Magnessium & $\mathrm{Mg}$ & 50 \\
\hline Iron & $\mathrm{Fe}$ & 12 \\
\hline Manganese & $\mathrm{Mn}$ & 2 \\
\hline Cupper & $\mathrm{Cu}$ & 0.1 \\
\hline Zinc & $\mathrm{Zn}$ & 0.1 \\
\hline Boron & $\mathrm{B}$ & 0.3 \\
\hline Molybdenum & $\mathrm{Mo}$ & 0.2 \\
\hline Sulfur & $\mathrm{S}$ & 69 \\
\hline
\end{tabular}

Statistical analysis, The analysis of variance of the effects of 10 treatments on the measurements of the collected parameters was performed using the GLM procedure of SPSS software. Combined analysis of variance over 2 years was performed for the vegetative, yield, chemical, and physiological analysis. (Gomez and Gomez, 1983).

\section{Data recorded}

- Data of fresh shoot weight (g), fresh root weight (g), dry shoot weight (g) dry root weight $(\mathrm{g})$ and dry leaves weight was recorded on three plants from each replicate at the flowering onset. (Samples were taken in the Sixth week of the experiment)

- Stem length, stem diameter and number of leaves were recorded at the end of the season after the Sixth harvest. (Samples were taken in the Sixth week of the experiment)
Leaf chlorophyll indicator (SPAD readings) was measured on tached $4^{\text {th }}$ leaves from the plant apex via chlorophyll meter device, the SPAD-502 plus by Konica Minolta. The chlorophyll SPAD reading was measured 4 times starting at flowering onset then every two weeks but the shown chlorophyll data is average of collected through 4 times data.

Fruits yield was determined as a marketable yield through summation of fruits weight for each harvest for each plant individually over six weeks.

Nutrient elements analysis, at flowering onset stage, the leaves which subjected to dry weight determination after drying at $70 \mathrm{C}^{\circ}$ it was digested, then the extract was used for measuring $\mathrm{N}, \mathrm{P}, \mathrm{K}$ and Fe, elements according to the procedures described by A.O.A.C. (1985).

Statistical analysis, The data were analyzed of complete randomized block design as mentioned by Gomez and 
M.E.M. Ahmed, et al.,

Gomez (1984), using statistical software Co Stat under windows for analysis of variance (ANOVA). The differences significances of among the combination of grafting and salinity treatments were determined according to Fisher's LSD test at $5 \%$ level. The displayed data are a combination of the data of the two growing seasons.

\section{RESULTS AND DISCUSSION \\ Vegetative growth parameters}

Data in from Figures 1 to 30 illustrated the response of vegetative growth parameters (fresh shoot weight, fresh root weight, dry shoot weight, dry root weight, dry leaves weight, stem length, stem diameter and number of leaves) of both grafted and non-grafted cucumber plants to the nutrient solution strength. Where all the parameters increased with increasing nutrient solution strength from $70 \%$ to $110 \%$. But the grafted plants showed a significantly superior response compared to non-grafted plants under each nutrient solution strength. Generally, the highest values of all parameters for both grafted and nongrafted plants were recorded with applying $100 \%$ nutrient solution strength where there is no increment in all parameters with moving nutrient solution strength from $100 \%$ to $110 \%$. It is not surprising to note this improved effect of grafting on cucumber plant growth. Where grafting cucumber plants increased plant root/shoot ratio (nontabulated data), this means a higher root area and subsequently, an increment of water and nutrient uptake which reflected on improving plant physiology and morphology parameters. Otherwise Davis et al., (2008b) reviewed that RNA, protein, and other small molecules which some causing signal transduction from the rootstock to the scion so directly affecting scion physiology. Similar results were found by Huang et al., (2010), Cansev and Ozgur (2010) and ElKersh et al., (2016). This is confirmed by the apparent amelioration of grafted cucumber plants growth parameters especially the leaves dry weight which reflecting more net assimilates and subsequently more increment in plant organs measuring.

\section{Fresh shoot weight}

Data in Figures (1\& 2) monitored the response of vegetative growth parameters (fresh shoot weight) In the first and second seasons of both grafted and non-grafted cucumber plants to the nutrient solution strength. Where all the parameters increased with increasing nutrient solution strength from $70 \%$ to $110 \%$. But the grafted plants showed a significantly superior response compared to non-grafted plants under each nutrient solution strength. Generally, the highest values of fresh shoot weight for both grafted and nongrafted plants were recorded with applying $100 \%$ nutrient solution strength where there is no increment in all parameters with moving nutrient solution strength from $100 \%$ to $110 \%$.

\section{Fresh root weight}

Data in Figures (3 \&4) monitored the response of vegetative growth parameters fresh root weight ) In the first and second seasons of both grafted and non-grafted cucumber plants to the nutrient solution strength. Where all the parameters increased with increasing nutrient solution strength from $70 \%$ to $110 \%$. nutrient solution strength with moving nutrient solution strength from $90 \%$ to $100 \%$. Where grafting cucumber plants increased plant root/shoot ratio (non-tabulated data), this means a higher root area and subsequently, an increment of water and nutrient uptake which 
reflected on improving plant physiology and morphology parameter.

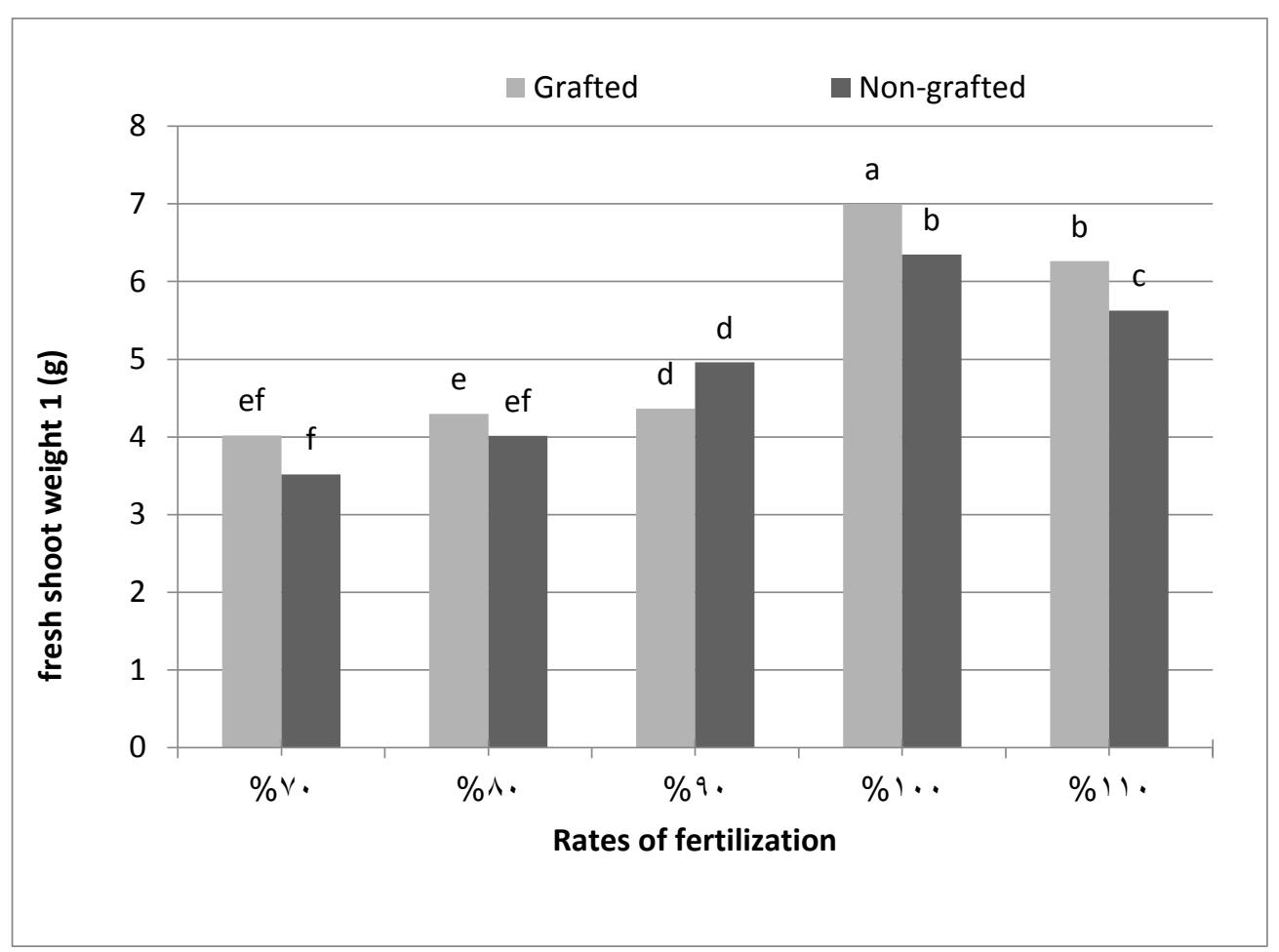

Figure 1: Effect of Nutrient Solution Strength on fresh shoot weight of Cucumber Grown Hydroponically in greenhouse $1^{\text {st }}$ Season.

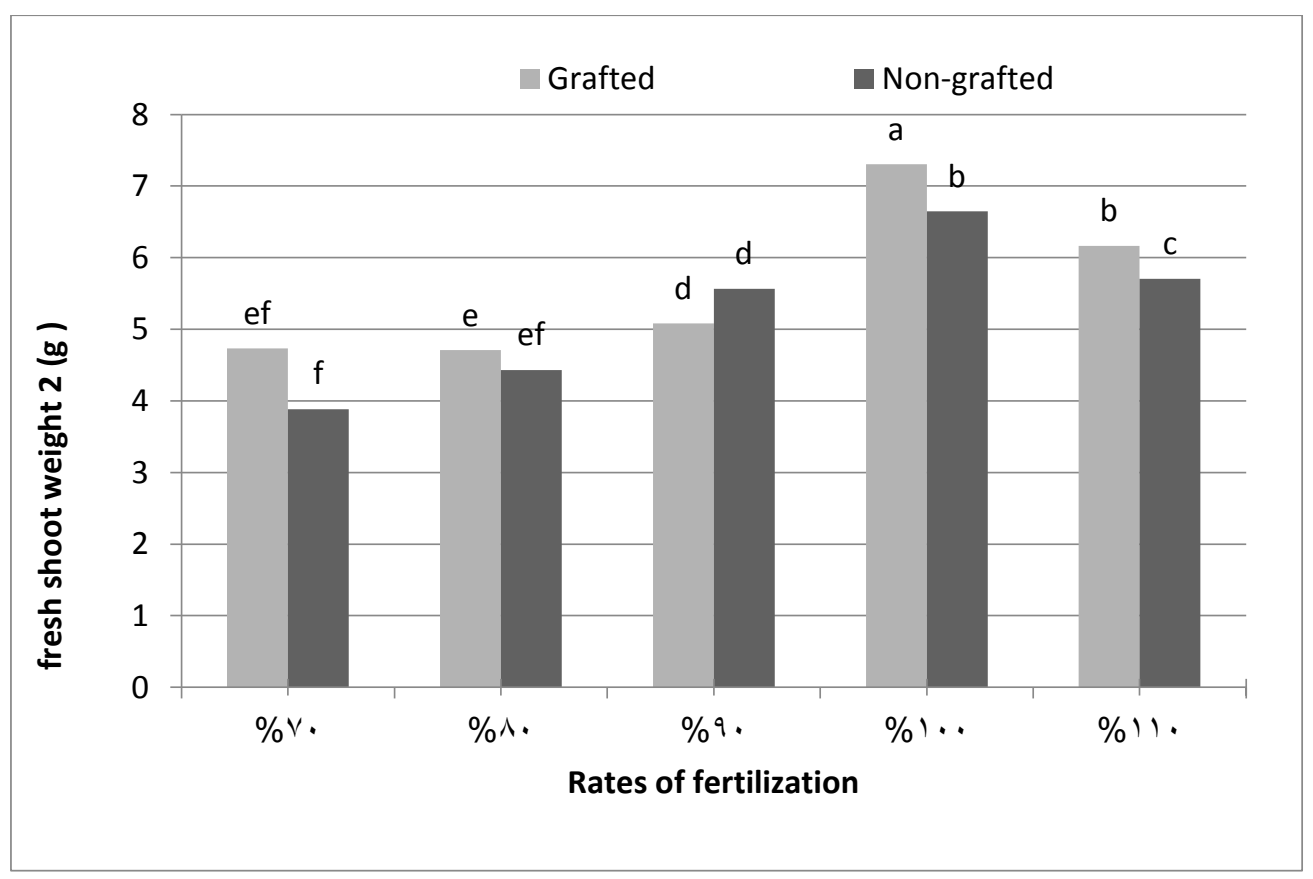

Figure 2: Effect of Nutrient Solution Strength on fresh shoot weight of Cucumber Grown Hydroponically in greenhouse $2^{\text {nd }}$ Season. 


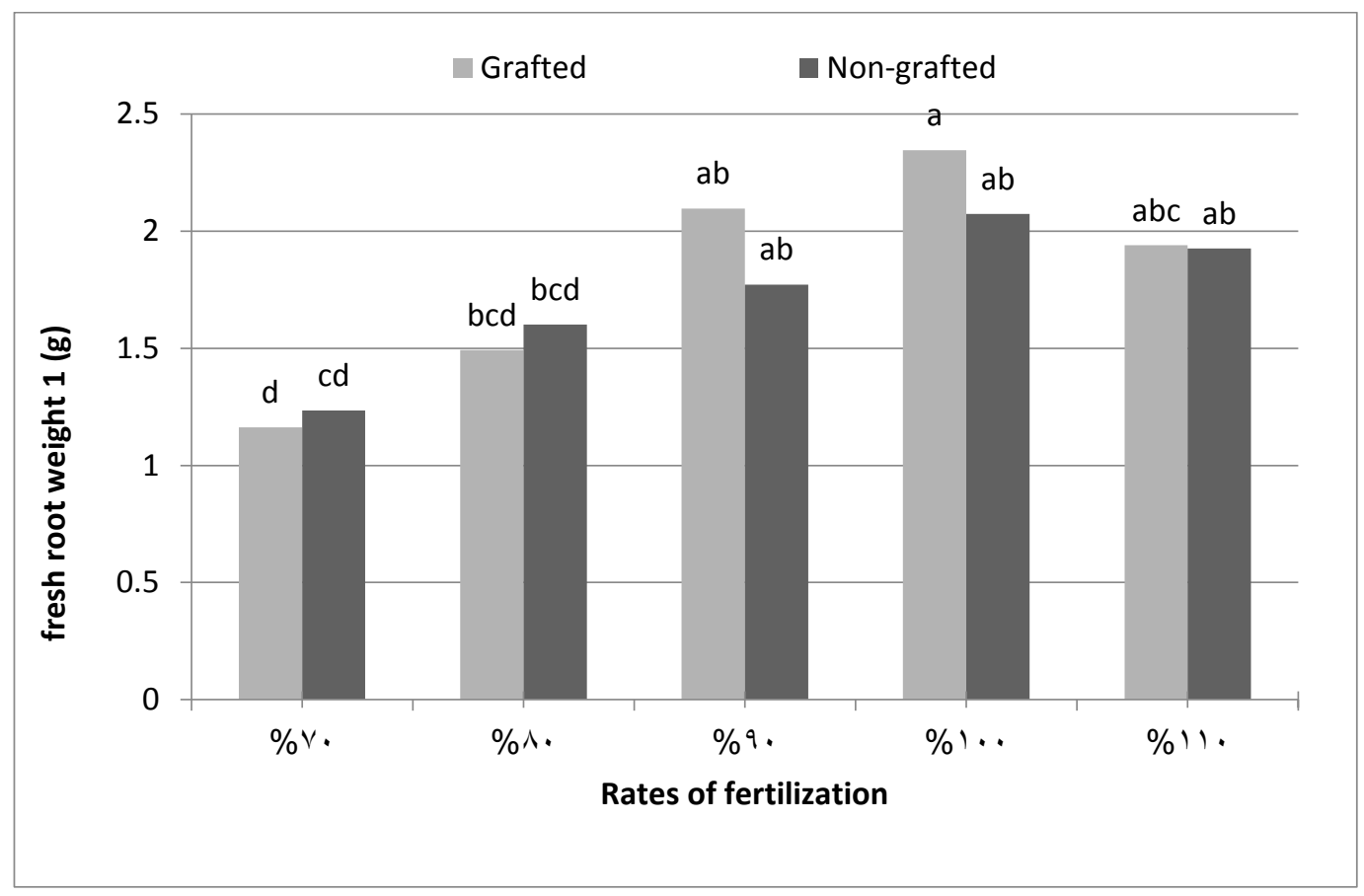

Figure 3: Effect of Nutrient Solution Strength on fresh root weight of Cucumber Grown Hydroponically in greenhouse $1^{\text {st }}$ Season.

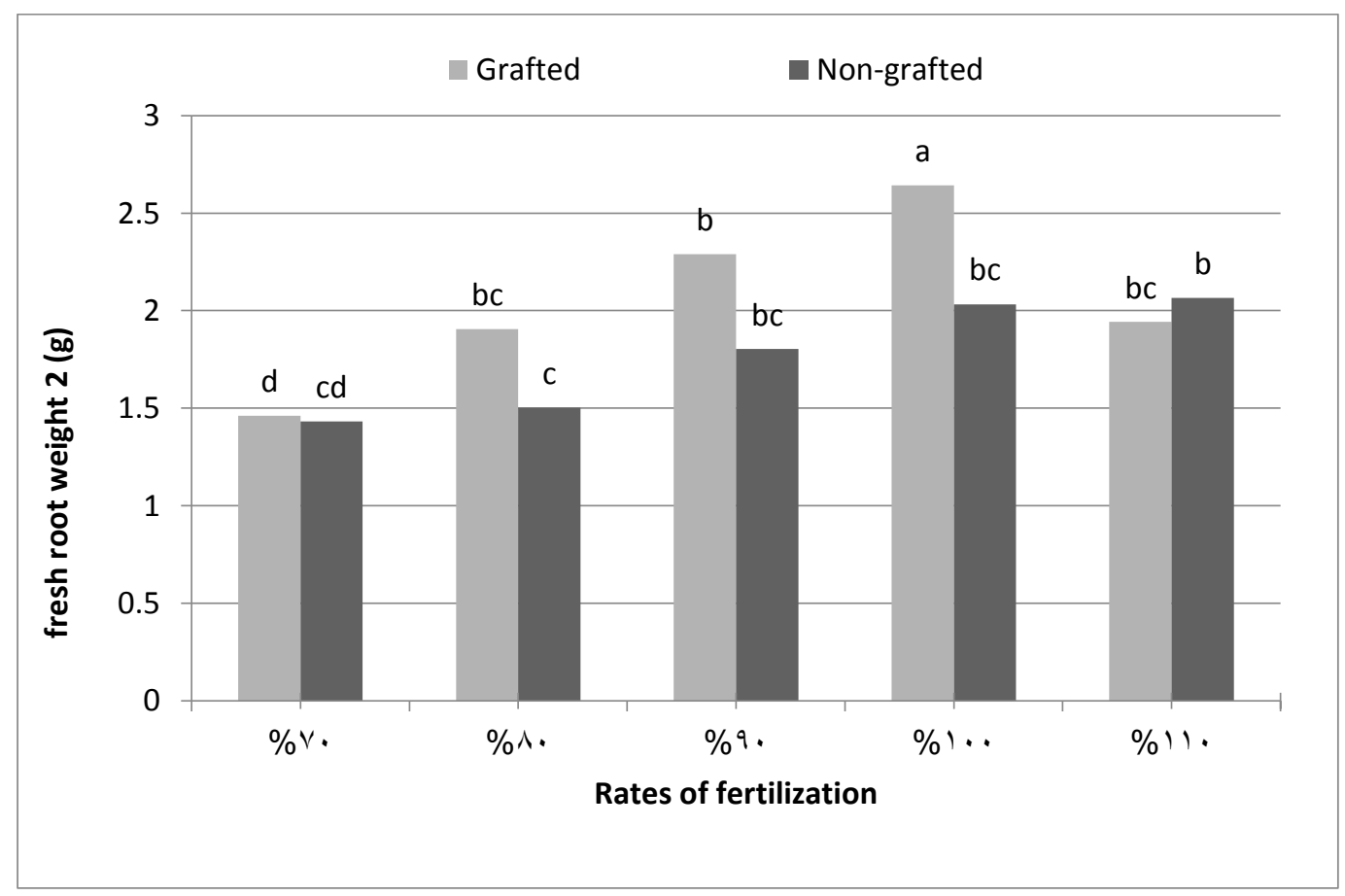

Figure 4: Effect of Nutrient Solution Strength on fresh root weight of Cucumber Grown Hydroponically in greenhouse $2^{\text {nd }}$ Season. 


\section{Dry shoot weight}

Data in Figures $(5 \& 6)$ monitored the response of growth parameters (dry shoot weight) In the first and second seasons of both grafted and non-grafted cucumber plants to the nutrient solution strength. Where dry shoot weight increased with increasing nutrient soluti

$$
\text { on }
$$

streng

th

from

$70 \%$

to

$110 \%$.

But

the

grafte

d

plants

showe

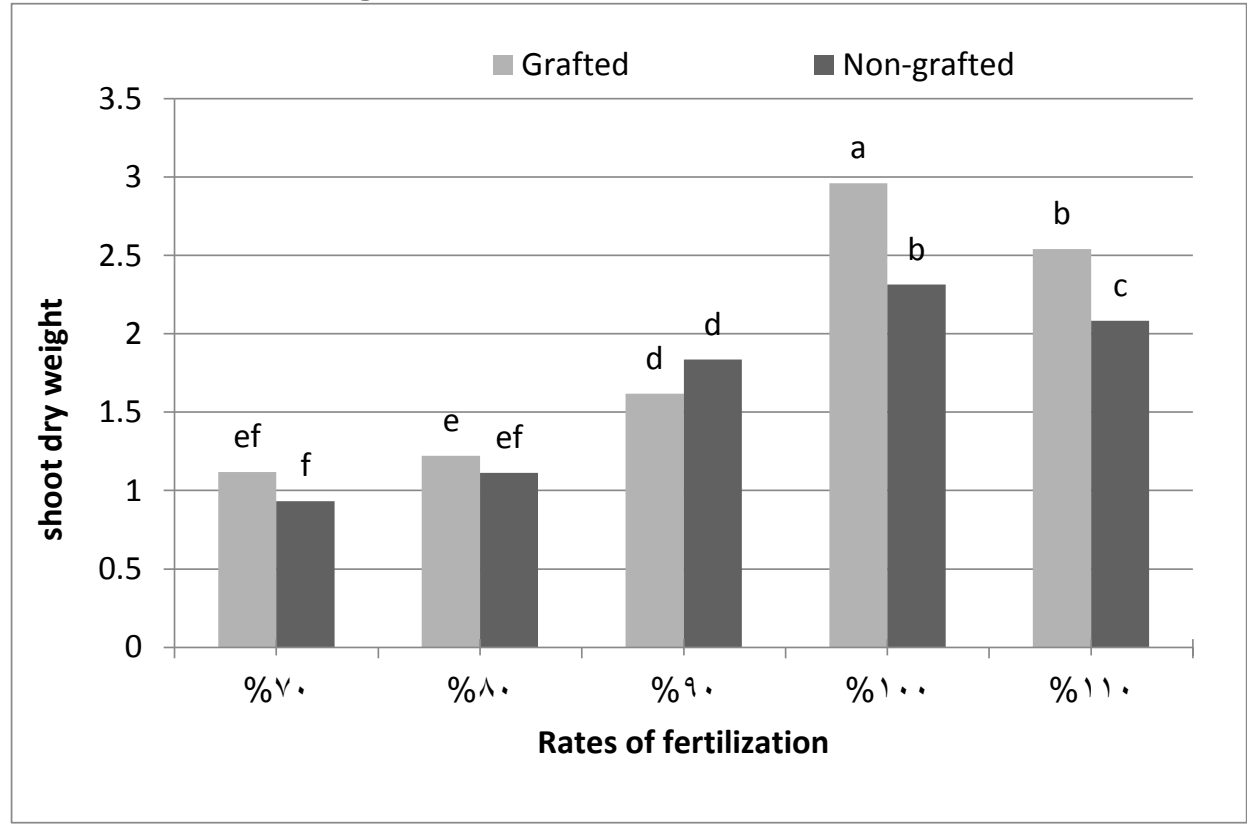

Figure 5: Effect of Nutrient Solution Strength on dry shoot weight of Cucumber Grown Hydroponically in greenhouse $1^{\text {st }}$ Season.

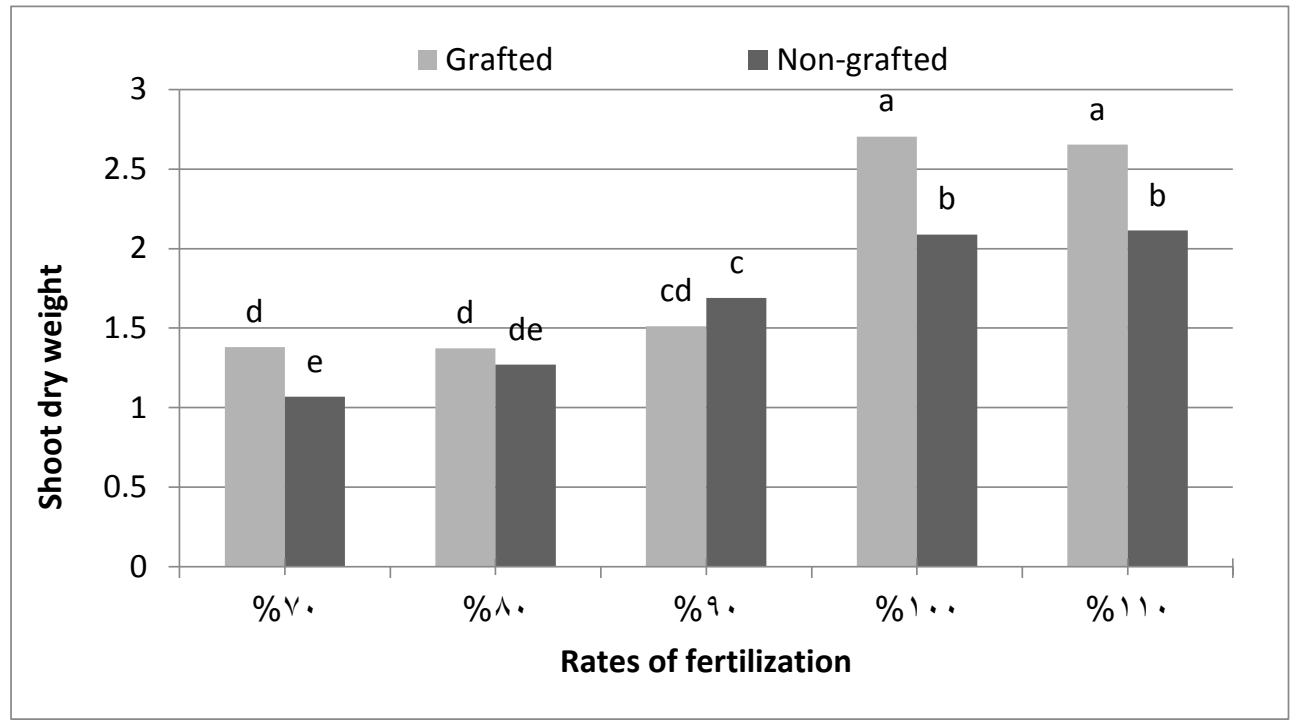

d a significantly superior response compared to non-grafted plants under each nutrient solution strength. Generally, the highest values of dry shoot weight for both grafted and nongrafted plants were recorded with applying $100 \%$ nutrient.

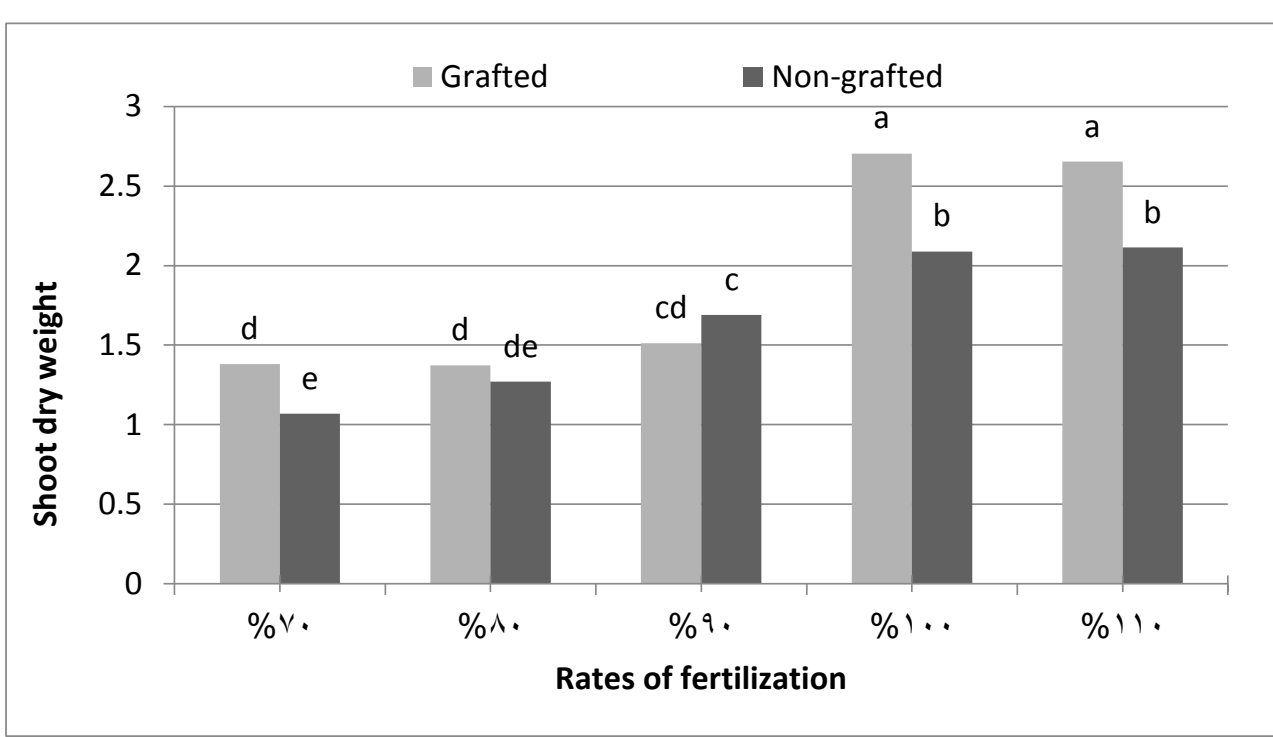


M.E.M. Ahmed, et al.,

Figure 6: Effect of Nutrient Solution Strength on dry shoot weight of Cucumber Grown Hydroponically in greenhouse $2^{\text {nd }}$ Season.

\section{Dry root weight}

Data in Figures (7 \&8) monitored the response of growth parameters (dry root weight) In the first and second seasons of both grafted and non-grafted cucumber plants to the nutrient solution strength. Where dry root weight increased with increasing nutrient solution strength from $70 \%$ to $110 \%$. But the grafted plants showed a significantly superior response compared to nongrafted plants under each nutrient solution strength. Generally, the highest values of dry root weight for both grafted and non- grafted plants were recorded with applying $100 \%$ nutrient solution strength.

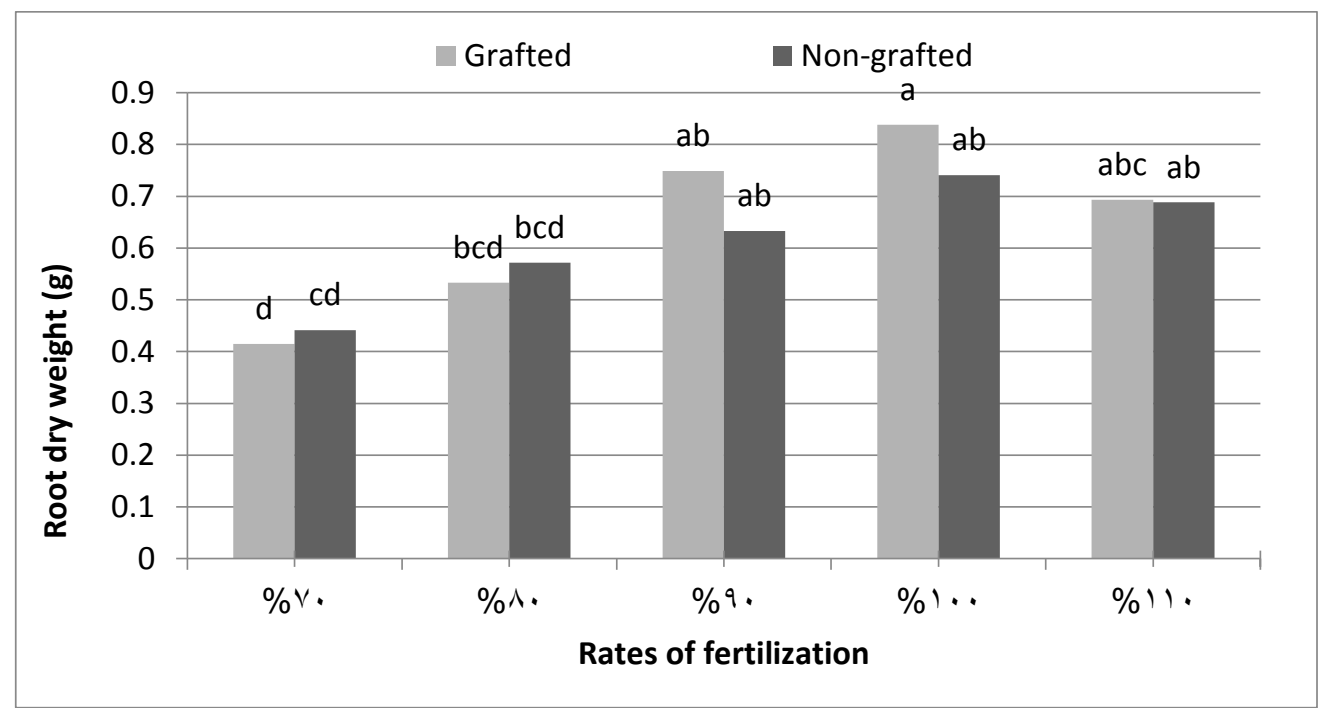

Figure 7: Effect of Nutrient Solution Strength on dry root weight of Cucumber Grown Hydroponically in greenhouse $1^{\text {st }}$ Season. 


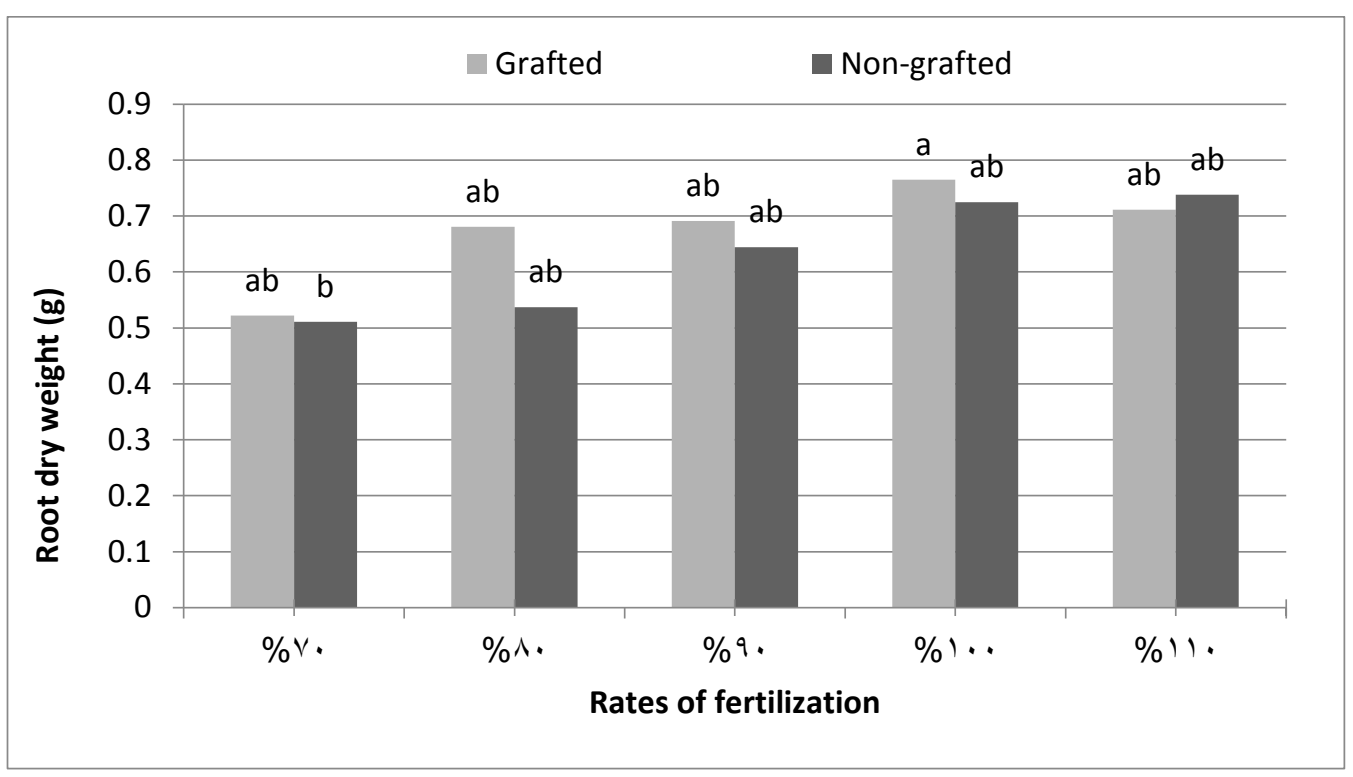

Figure 8: Effect of Nutrient Solution Strength on dry root weight of Cucumber Grown Hydroponically in greenhouse $2^{\text {nd }}$ Season.

\section{Dry leaves weight}

Data in Figures ( 9 \& 10 ) monitored the response of growth parameters (dry leaves weight) In the first and second seasons of both grafted and non-grafted cucumber plants to the nutrient solution strength. Where dry root weight increased with increasing nutrient solution strength from $70 \%$ to $110 \%$. But the grafted plants showed a significantly superior response compared to nongrafted plants under each nutrient solution strength. Generally, the highest values of dry leaves weight for both grafted and non- grafted plants were recorded with applying $100 \%$ nutrient solution strength. This is confirmed by the apparent amelioration of grafted cucumber plants growth parameters especially the leaves dry weight which reflecting more net assimilates and subsequently more increment in plant organs measuring.

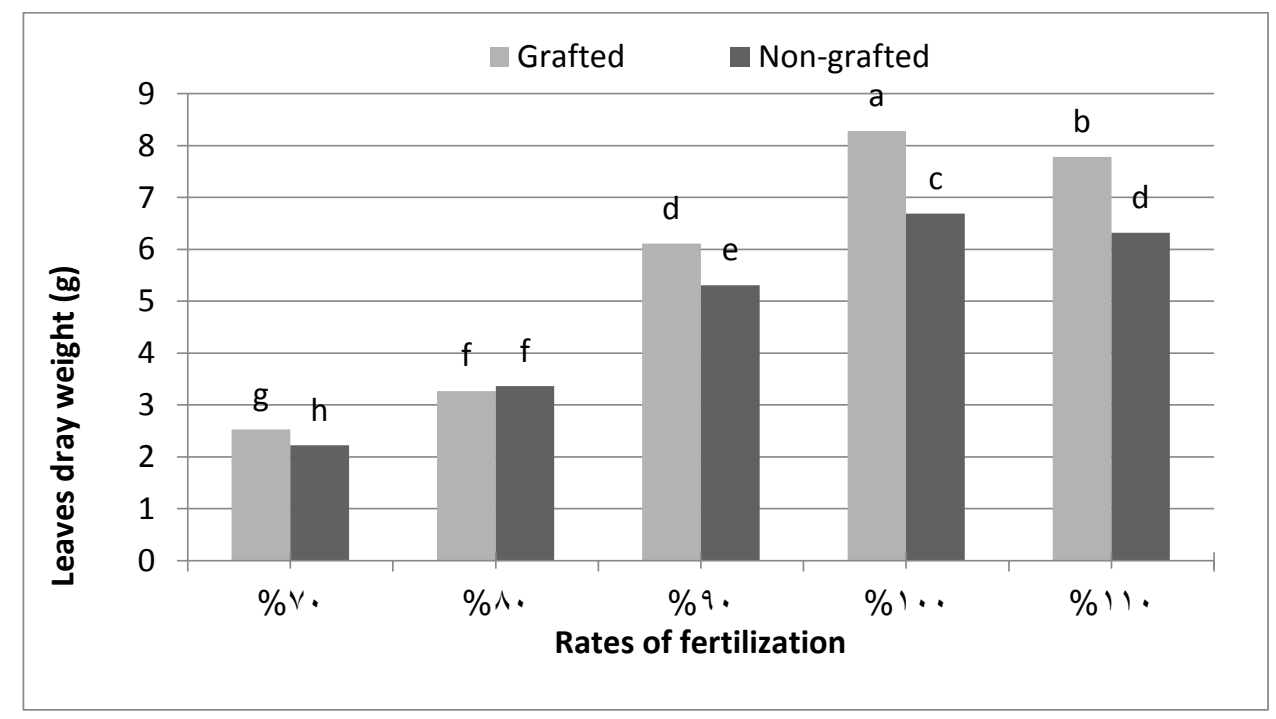


M.E.M. Ahmed, et al.,

Figure 9: Effect of Nutrient Solution Strength on dry leaves weight of Cucumber Grown Hydroponically in greenhouse $1^{\text {st }}$ Season.

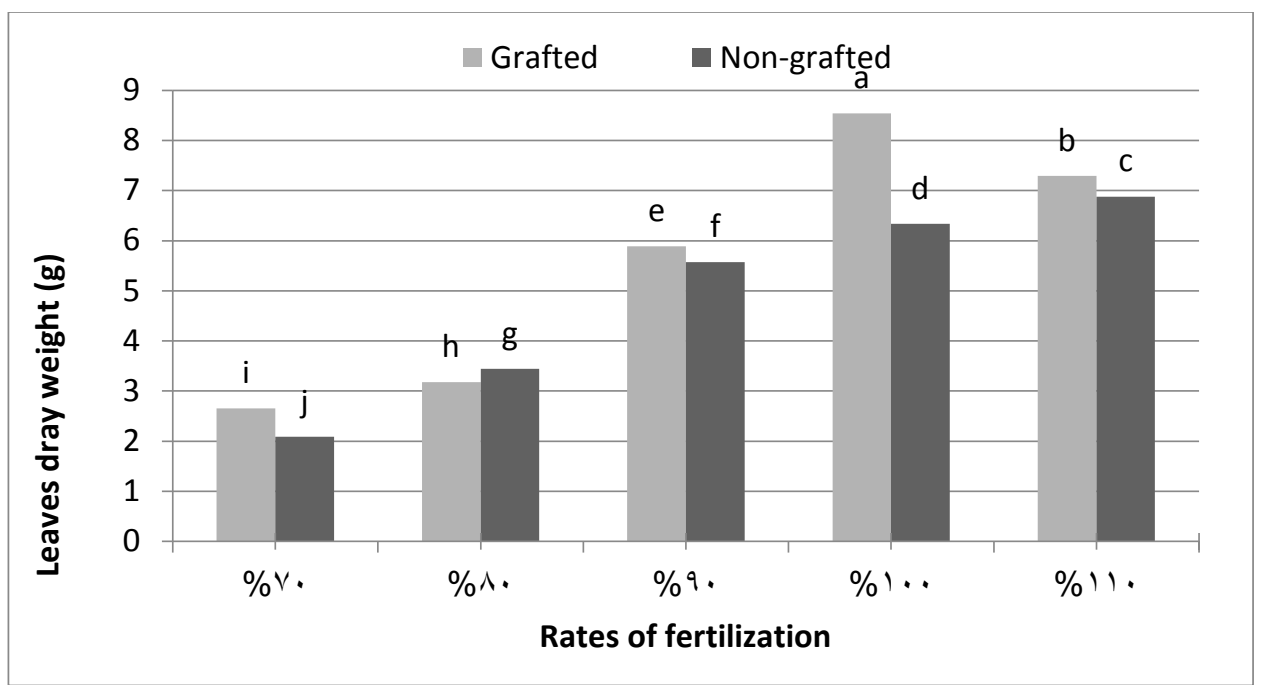

Figure 10: Effect of Nutrient Solution Strength on dry leaves weight of Cucumber Grown Hydroponically in greenhouse $2^{\text {nd }}$ Season.

\section{Stem length}

Data in Figures ( $11 \& 12$ ) monitored the response of vegetative growth parameters (stem length) In the first and second seasons of both grafted and nongrafted cucumber plants to the nutrient Where all the parameters increased with increasing nutrient solution strength from $70 \%$ to $110 \%$. But the grafted plants showed a significantly superior response compared to non-grafted plants solution strength. under each nutrient solution strength. the highest values of all parameters for both grafted and nongrafted plants were recorded with applying $100 \%$ nutrient solution to note this improved effect of grafting on cucumber plant growth. Where grafting cucumber plants increased Stem length , an increment of water and nutrient uptake which reflected on improving plant physiology and morphology parameters. which reflecting more net assimilates and subsequently more increment in plant organs measuring .

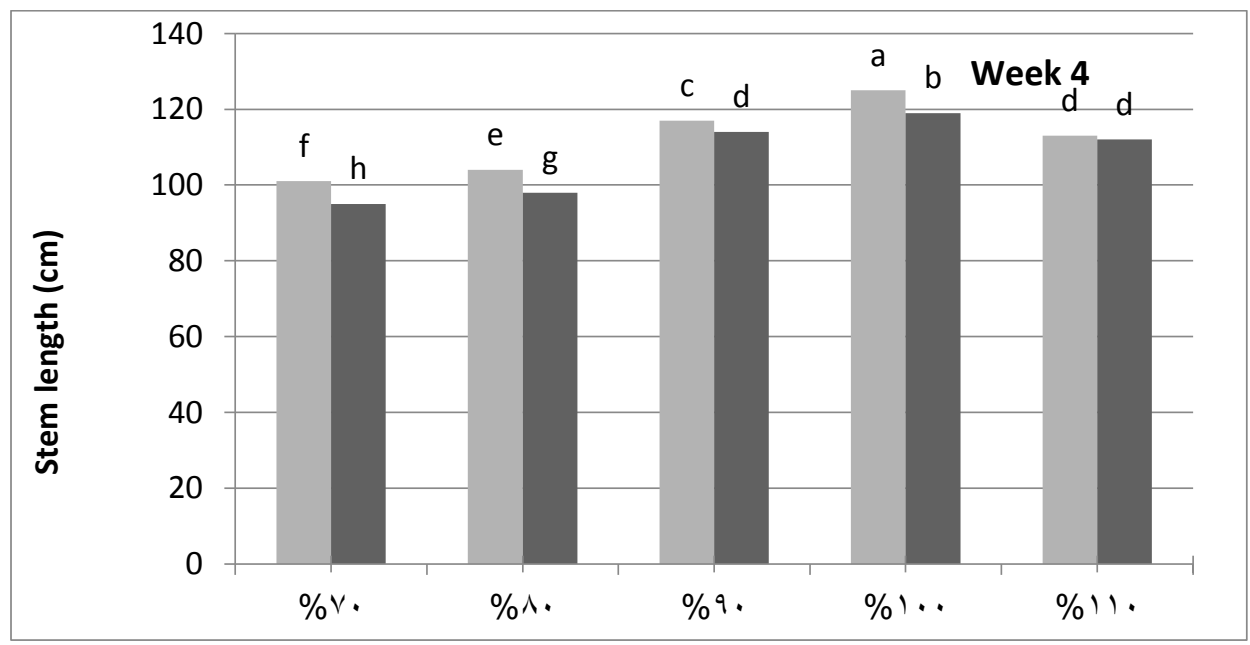


Figure 11: Effect of Nutrient Solution Strength on Stem length of Cucumber Grown Hydroponically in greenhouse $1^{\text {st }}$ Season.

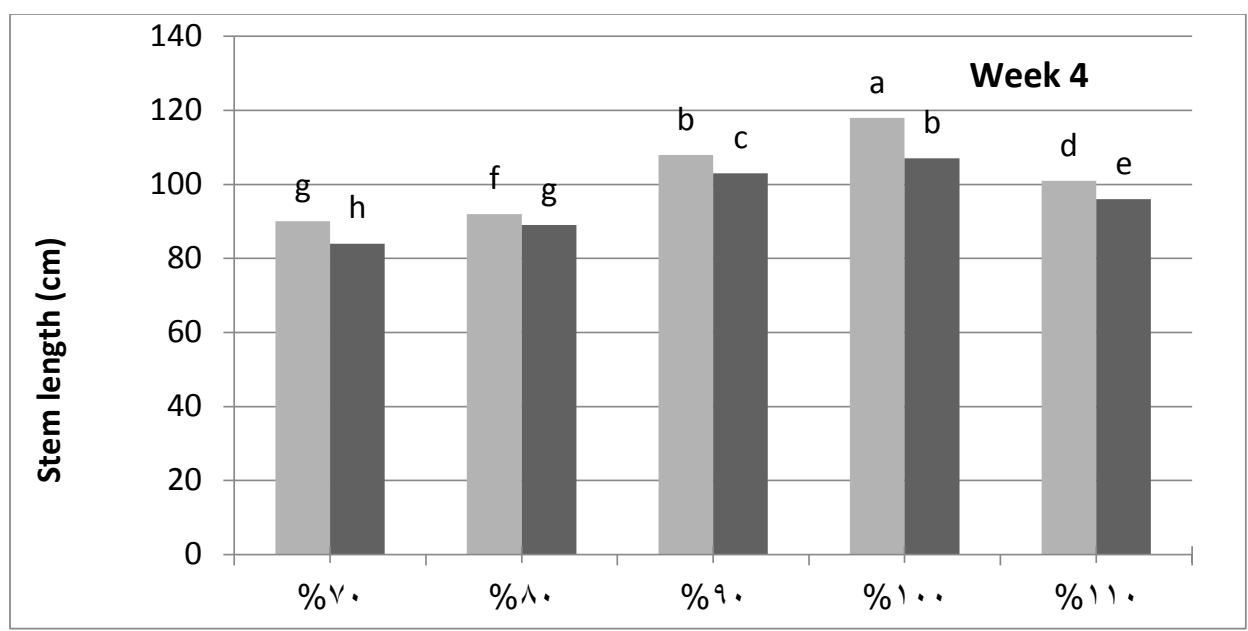

Figure 12: Effect of Nutrient Solution Strength on Stem length of Cucumber Grown Hydroponically in greenhouse $2^{\text {nd }}$ Season.

\section{Stem diameter}

Data in Figure (13 \& 14 ) monitored the response of vegetative growth parameters (Stem diameter) In the first and second seasons of both grafted and non-grafted cucumber plants to the nutrient Where all the parameters increased with increasing nutrient solution strength from $70 \%$ to $110 \%$. But the grafted plants showed a significantly superior response compared to nongrafted plants solution strength. under each nutrient solution strength. the highest values of all parameters for both grafted and non- grafted plants were recorded with applying $90 \%$ and $100 \%$ nutrient solution to note this improved effect of grafting on cucumber plant growth. Where grafting cucumber plants increased Stem diameter, an increment of water and nutrient uptake which reflected on improving plant physiology and morphology parameters. which reflecting more net assimilates and subsequently more increment in plant organs measuring. 
M.E.M. Ahmed, et al.,

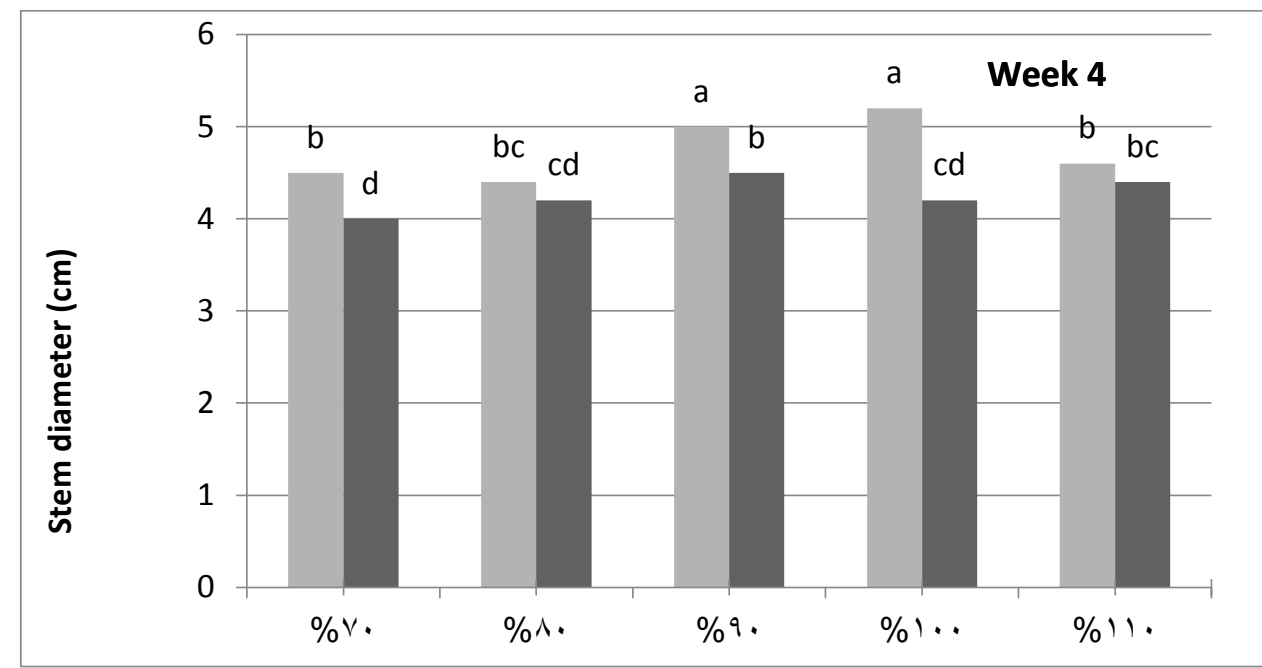

Figure 13: Effect of Nutrient Solution Strength on Stem diameter of Cucumber Grown Hydroponically in greenhouse $1^{\text {st }}$ Season.

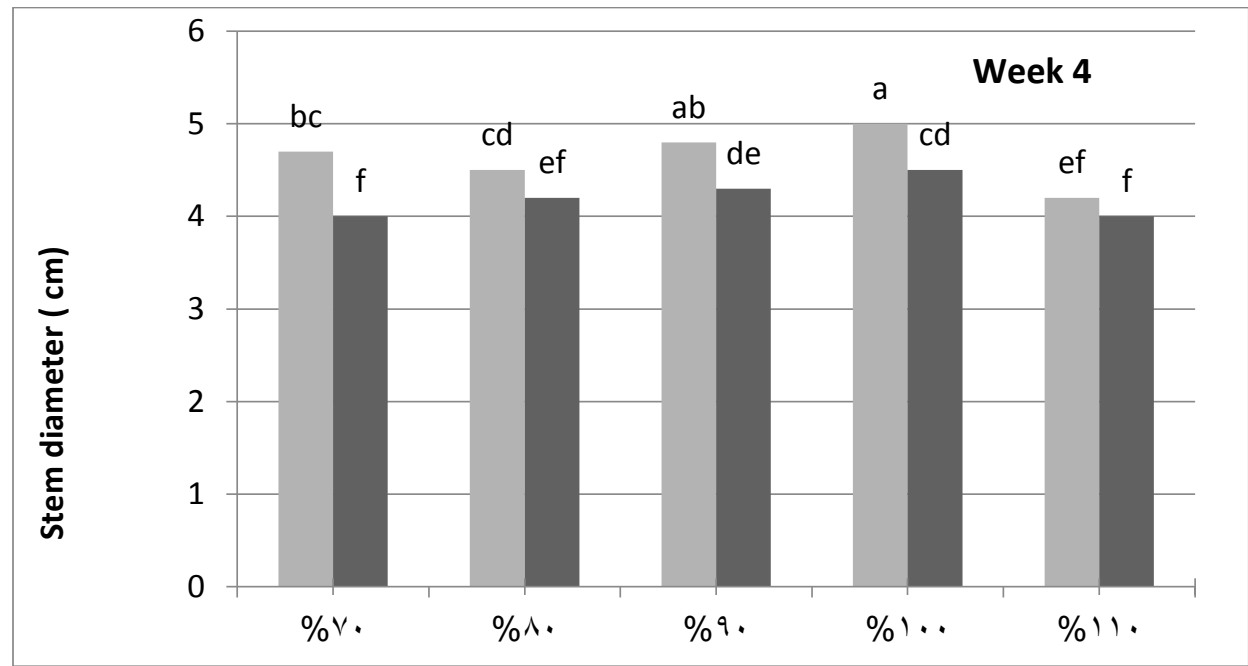

Figure 14: Effect of Nutrient Solution Strength on Stem diameter of Cucumber Grown Hydroponically in greenhouse $2^{\text {nd }}$ Season.

\section{Number of leaves}

Data in Figures (15 \& 16) monitored the response of vegetative growth parameters (Number of leaves) in the first and second seasons of both grafted and non-grafted cucumber plants to the nutrient Where all the parameters increased with increasing nutrient solution strength from $70 \%$ to $110 \%$. But the grafted plants showed a significantly superior response compared to nongrafted plants solution strength. under each nutrient solution strength. the highest values of all parameters for both grafted and non- grafted plants were recorded with applying $80 \%, 100 \%$ and $100 \%$ nutrient solution to note this improved effect of grafting on cucumber plant growth. Where grafting cucumber plants increased Number of leaves, an increment of water and nutrient uptake which reflected on improving plant physiology and morphology parameters. which reflecting more net assimilates and subsequently more increment in plant organs measuring growth parameters especially the Number of leaves which reflecting more net assimilates and 
subsequently more increment in plant organs measuring.

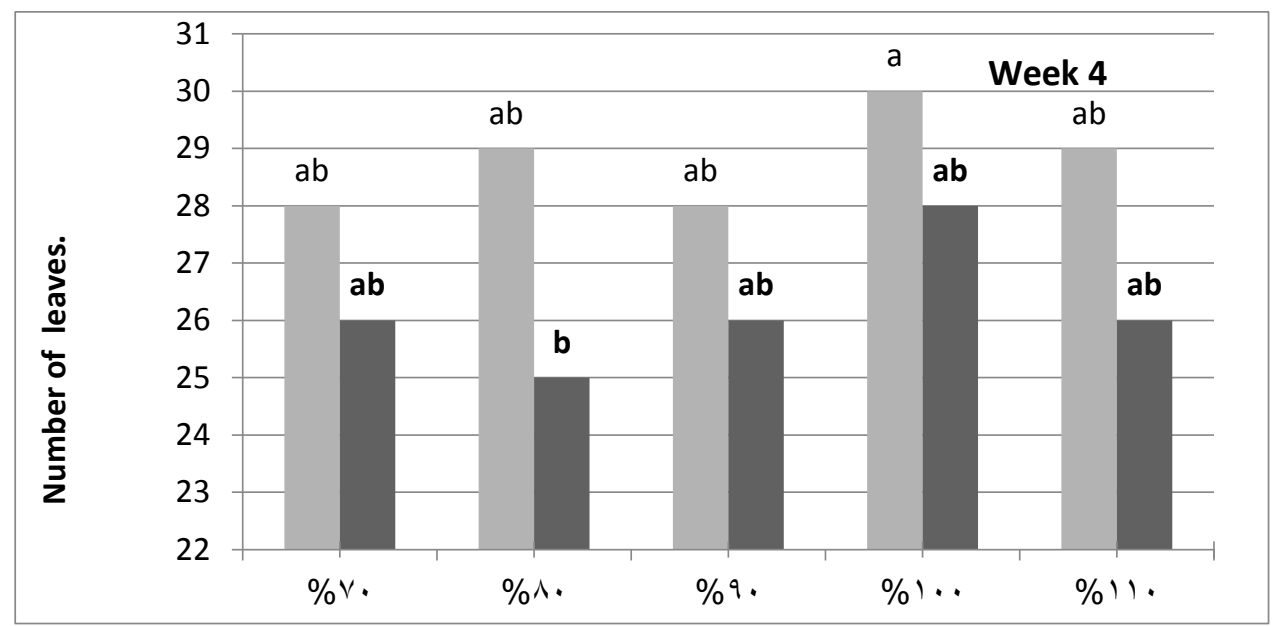

Figure 15: Effect of Nutrient Solution Strength on Number of leaves of Cucumber Grown Hydroponically in greenhouse $1^{\text {st }}$ Season.

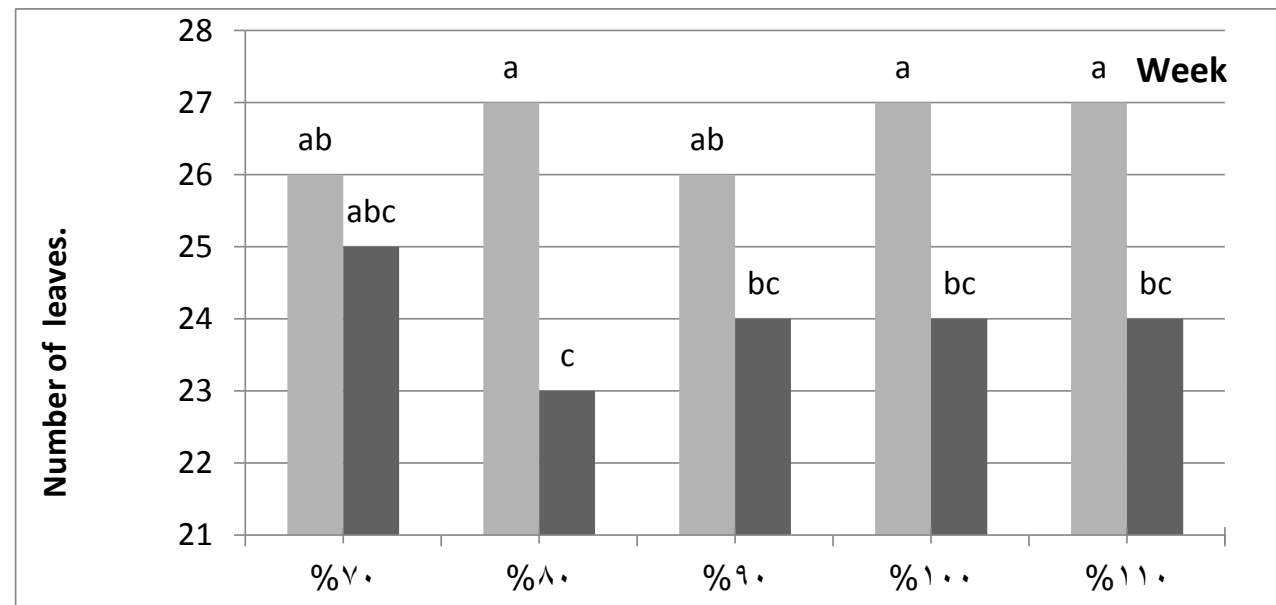

Figure 16: Effect of Nutrient Solution Strength on Number of leaves of Cucumber Grown Hydroponically in greenhouse $2^{\text {nd }}$ Season.

\section{Clorophyll indicator of leaves}

Chlorophyll SPAD reading, as an indicator of plant leaves greening degree or its chlorophyll content, refers to the plant physiological status (Süß et al, 2015). The data of figure, 9 clarify the chlorophyll SPAD reading of grafted and non-grafted cucumber leaves under different nutrient solution strengths from $70 \%$ to $110 \%$. The data in (Figure $17 \& 18$ ) proved that grafted plants leaves were more greening than non-grafted others under each nutrient solution strength. The leaves greening status was improved with rising nutrient solution strength in both grafted and non-grafted plants. The highest leaves greening degree was recorded in grafted plants supplied with $100 \%$ nutrient solution strength. It is well known that chlorophyll pigment is a key biochemical component responsible for photosynthesis and carbon assimilation and affected by water and nutrients absorption. El-Kersh et al., (2016) found that using pumpkins rootstock increased the root volume compared with selfrooted plants, this also proved by the data in figures 2 and 4 , subsequently increasing all plant metabolisms that 
M.E.M. Ahmed, et al.,

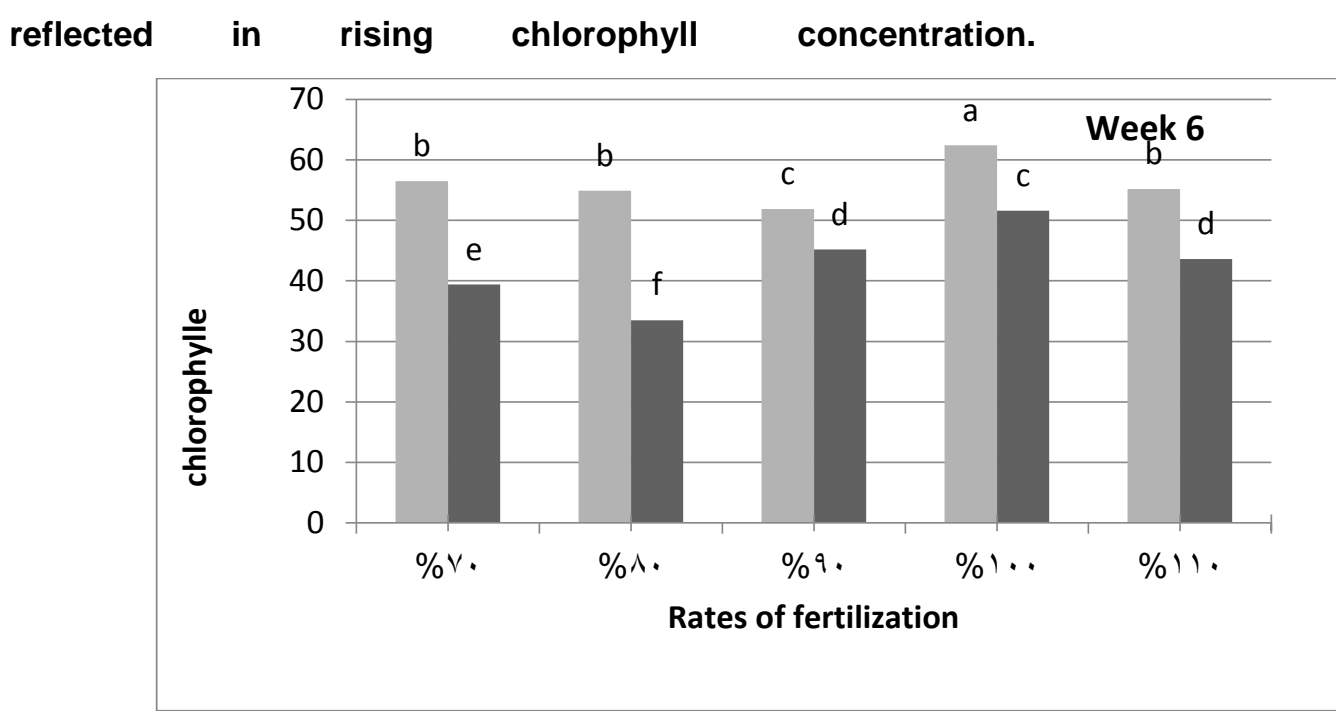

Figure 17: Effect of Nutrient Solution Strength on Chlorophyll indicator of leaves of Cucumber Grown Hydroponically in greenhouse $1^{\text {st }}$ Season.

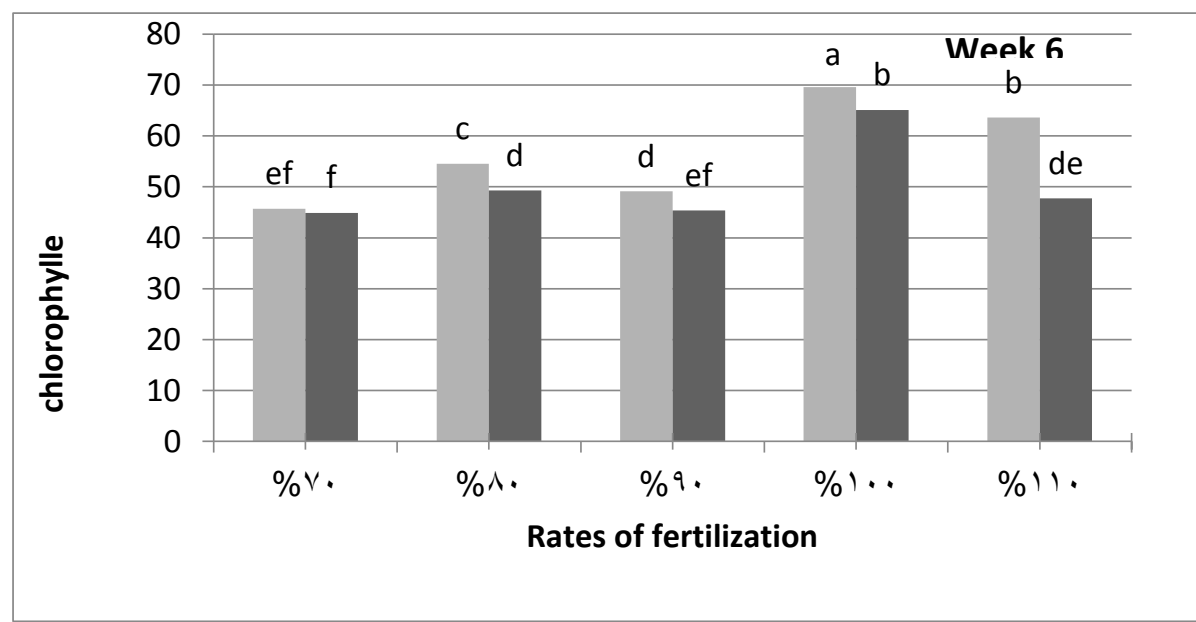

Figure 18: Effect of Nutrient Solution Strength on Chlorophyll indicator of leaves of Cucumber Grown Hydroponically in greenhouse $2^{\text {nd }}$ Season.

Nutrient elements contents in plant leaves

\section{Nitrogen}

Data in Figures (19 \& 20) monitored the response of vegetative growth parameters activity rate of the plant. Nitrogen, content in the experimented cucumber plants leaves appeared to be affected by nutrient solution strength and grafting the nutrient concentration in the cucumber plants leaves increased with rising nutrient solution strength to $100 \%$ then did not increase but in some cases it decreased with $110 \%$ nutrient solution concentration. nutrients concentration in root rhizosphere increases these nutrients concentration in the plant, the grafted cucumber plants showed higher leaves Nitrogen. 


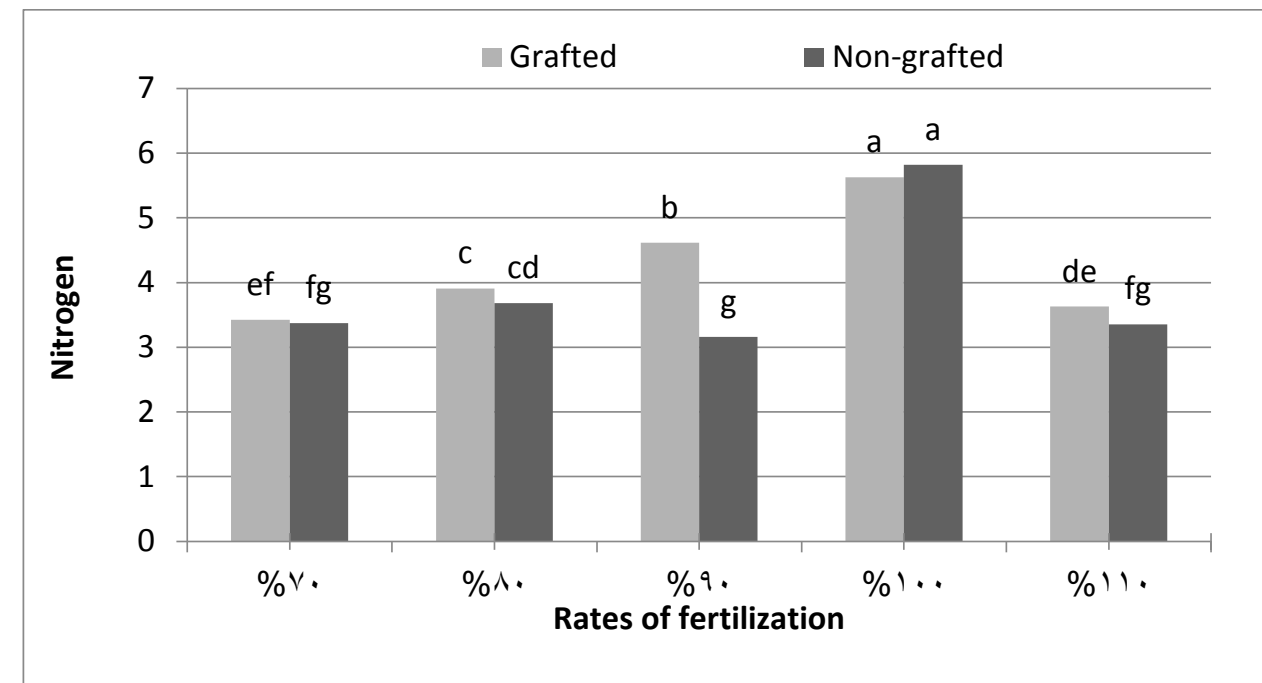

Figure 19: Effect of Nutrient Solution Strength on Nitrogen of Cucumber Grown Hydroponically in greenhouse $1^{\text {st }}$ Season.

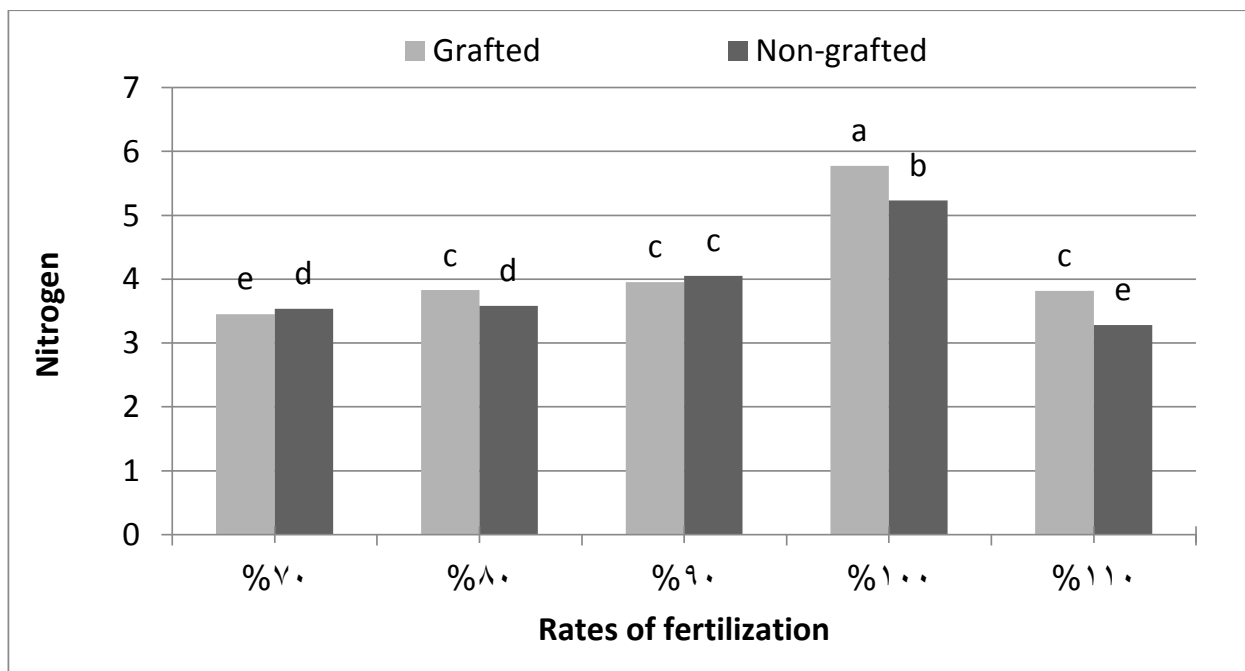

Figure 20: Effect of Nutrient Solution Strength on Nitrogen of Cucumber Grown Hydroponically in greenhouse $2^{\text {nd }}$ Season.

\section{Phosphorus}

Data in Figures ( 21 \& 22 ) monitored the response of vegetative growth parameters activity rate of the plant. Phosphorus, content in the experimented cucumber plants leaves appeared to be affected by nutrient solution strength and grafting the nutrient concentration in the cucumber plants leaves increased with rising nutrient solution strength to $100 \%$ nutrient solution concentration. Nutrients concentration in root rhizosphere increases these nutrients concentration in the plant, the grafted cucumber plants showed higher leaves Phosphorus, Thus stimulating the rooting process 
M.E.M. Ahmed, et al.,

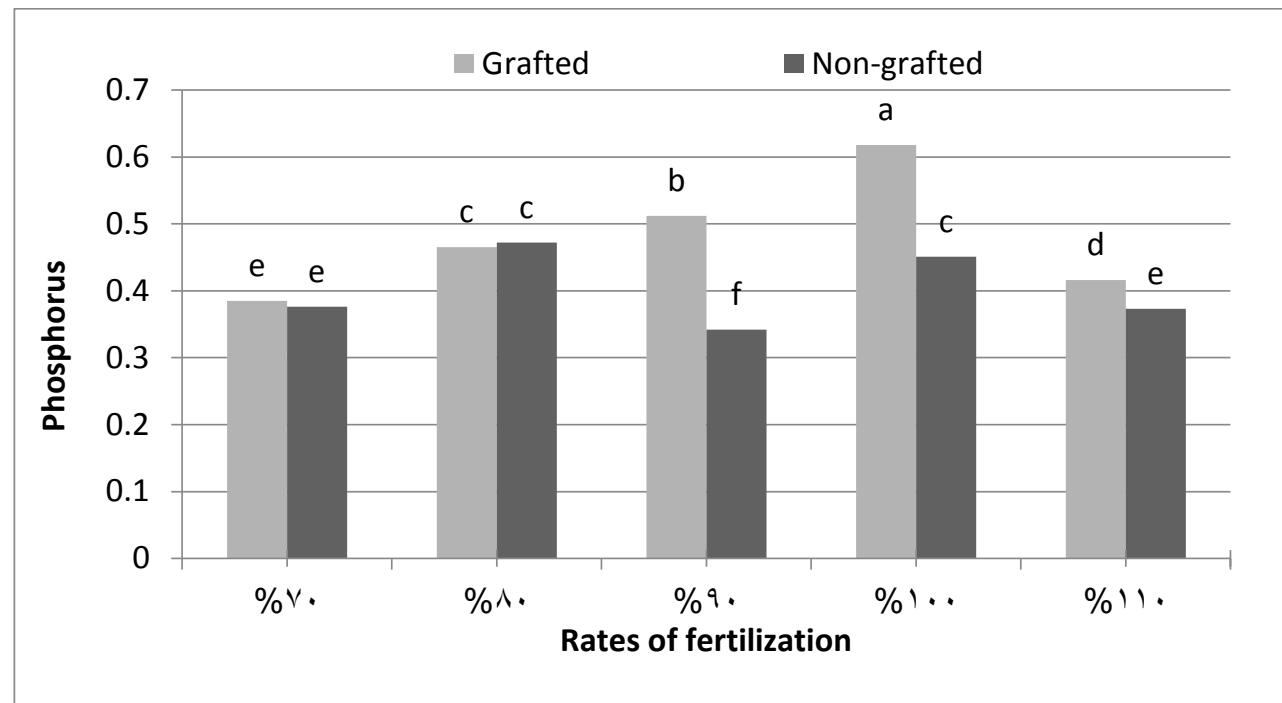

Figure 21: Effect of Nutrient Solution Strength on Phosphorus of Cucumber Grown Hydroponically in greenhouse $1^{\text {st }}$ Season.

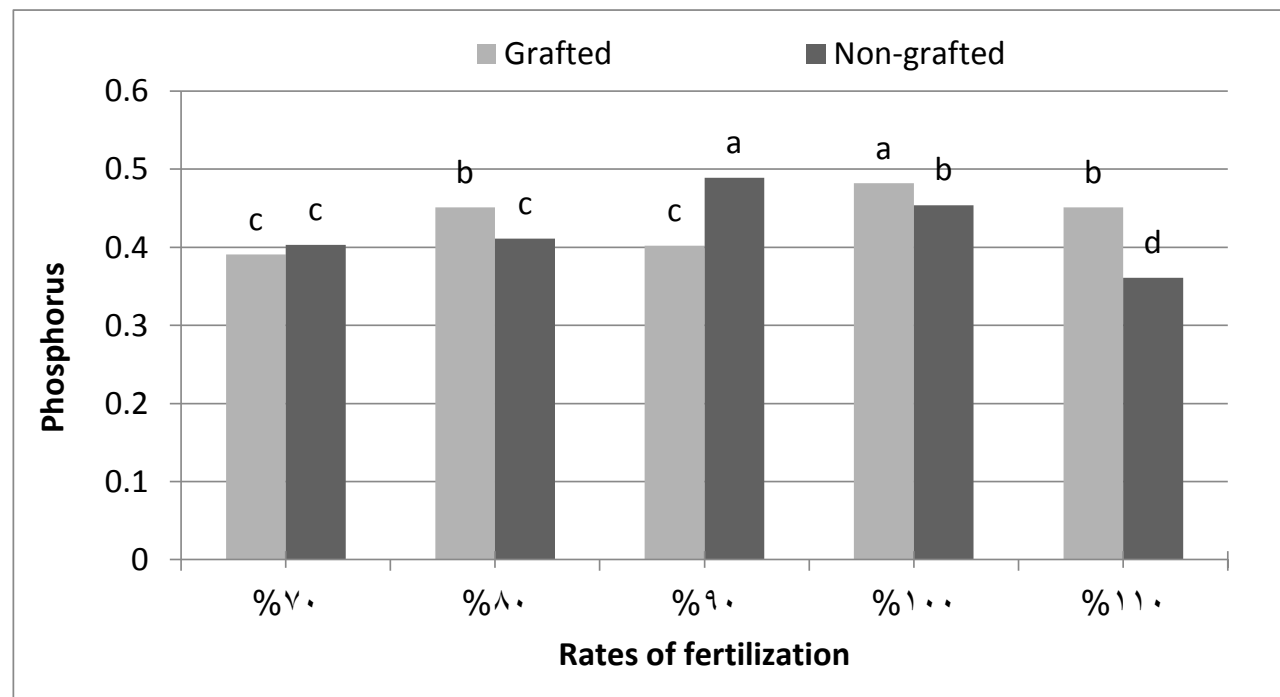

Figure 22: Effect of Nutrient Solution Strength on Phosphorus of Cucumber Grown Hydroponically in greenhouse $2^{\text {nd }}$ Season.

\section{Potassium}

Data in Figures ( $23 \& 24$ ) monitored the response of vegetative growth parameters activity rate of the plant. Potassium, content in the experimented cucumber plants leaves appeared to be affected by nutrient solution strength and grafting the nutrient concentration in the cucumber plants leaves increased with rising nutrient solution strength to $100 \%$ nutrient solution concentration. nutrients concentration in root rhizosphere increases these nutrients concentration in the plant, the grafted cucumber plants showed higher leaves Potassium, Thus strengthening and stimulating flowering and Holding fruits 


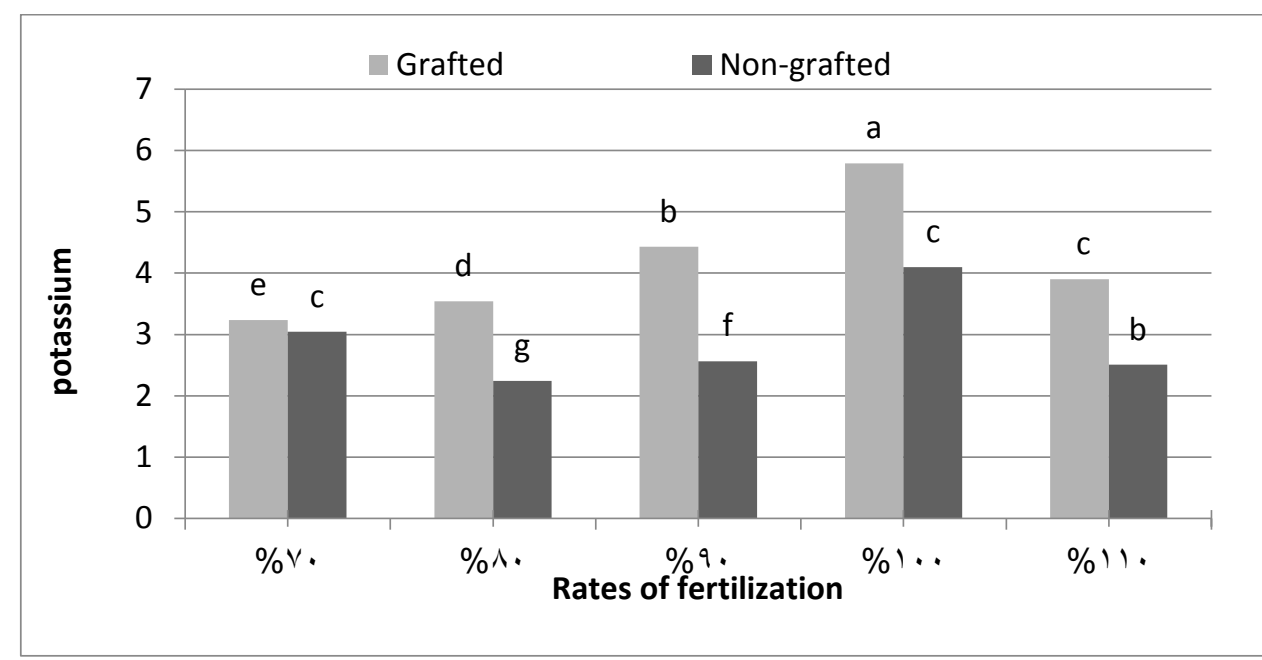

Figure 23: Effect of Nutrient Solution Strength on Potassium of Cucumber Grown Hydroponically in greenhouse $1^{\text {st }}$ Season.

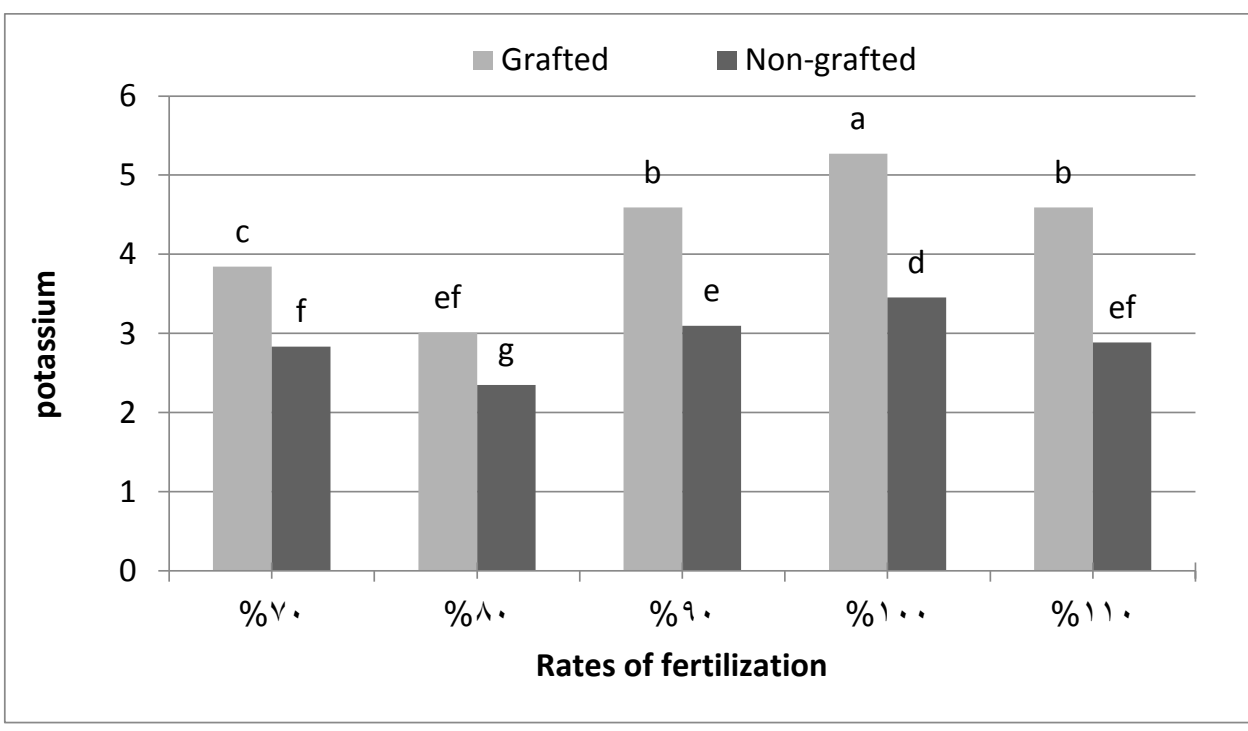

Figure 24: Effect of Nutrient Solution Strength on Potassium of Cucumber Grown Hydroponically in greenhouse $2^{\text {nd }}$ Season.

Iron (Fe)

Iron, content in the experimented cucumber plants leaves appeared to be affected by nutrient solution strength and grafting. (Figures 25 \& 26) The Fe concentration in the cucumber plants leaves increased with rising nutrient solution strength to $90 \%$ and $100 \%$ of nutrient solution concentration, Since nutrients concentration in root rhizosphere increases these nutrients concentration in the plant. The grafted cucumber plants showed higher leaves Iron, Thus stimulating vegetative growth parameters Iron It plays in essential mediating role in the formation of chlorophyll and does not go into its composition. It is included in the synthesis of cytokrium, so it plays an 
M.E.M. Ahmed, et al.,

essential role in respiration. It plays a key

the leaves to protein.

role in converting dissolved nitrogen in

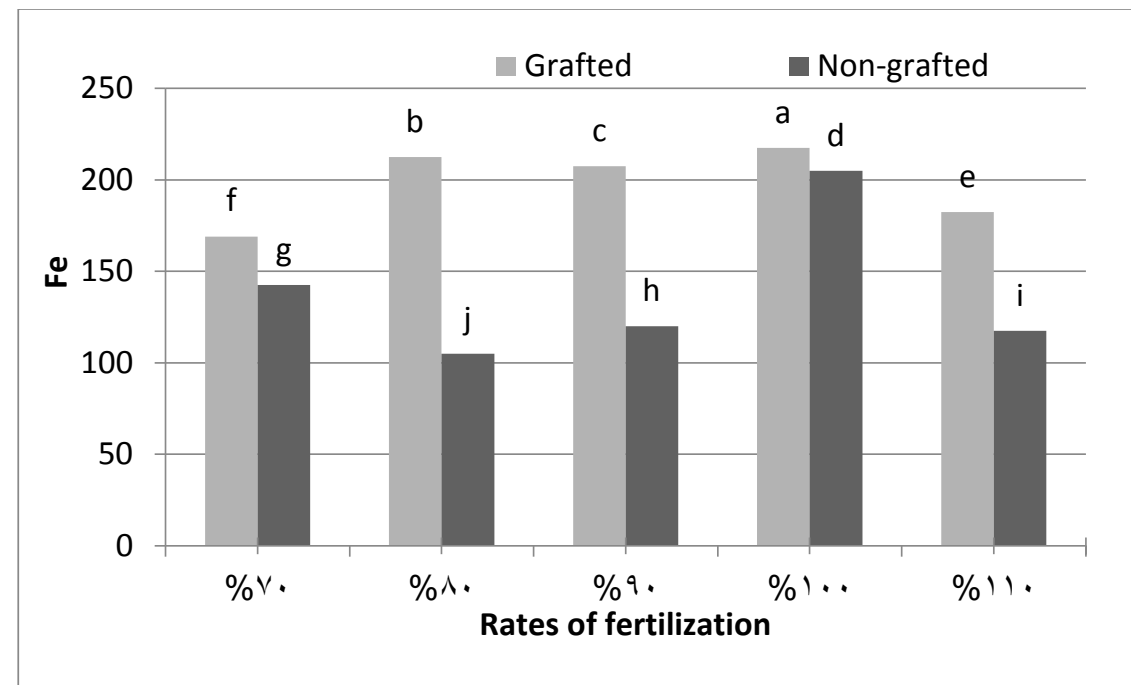

Figure 25: Effect of Nutrient Solution Strength on Iron of Cucumber Grown Hydroponically in greenhouse $1^{\text {st }}$ Season.

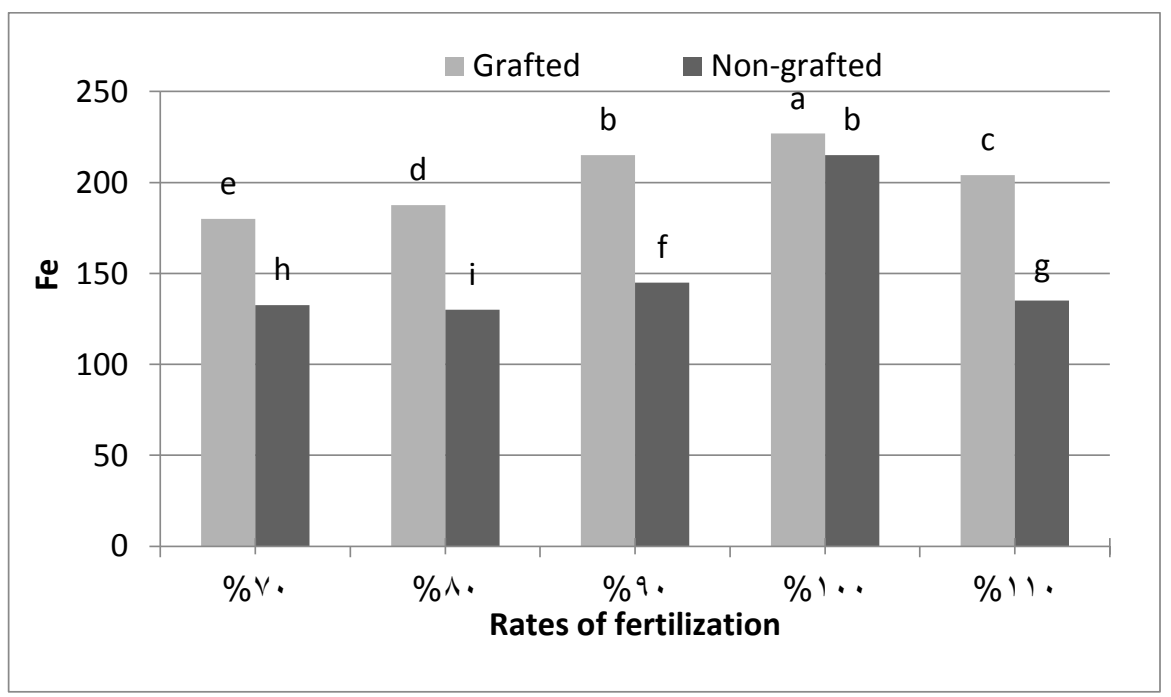

Figure 26: Effect of Nutrient Solution Strength on Iron of Cucumber Grown Hydroponically in greenhouse $2^{\text {nd }}$ Season.

\section{Copper ( $\mathrm{Cu}$ )}

Copper, content in the experimented cucumber plants leaves appeared to be affected by nutrient solution strength and grafting (Figures 27\&28) the nutrient concentration in the cucumber plants leaves increased with rising nutrient solution strength to $100 \%$ nutrient solution concentration. nutrients concentration in root rhizosphere increases these nutrients concentration in the plant, the grafted cucumber plants showed higher leaves Copper, Thus stimulating vegetative growth parameters it is involved in the formation of some enzymes that play an important role in 
the oxidation and reduction reactions in plants

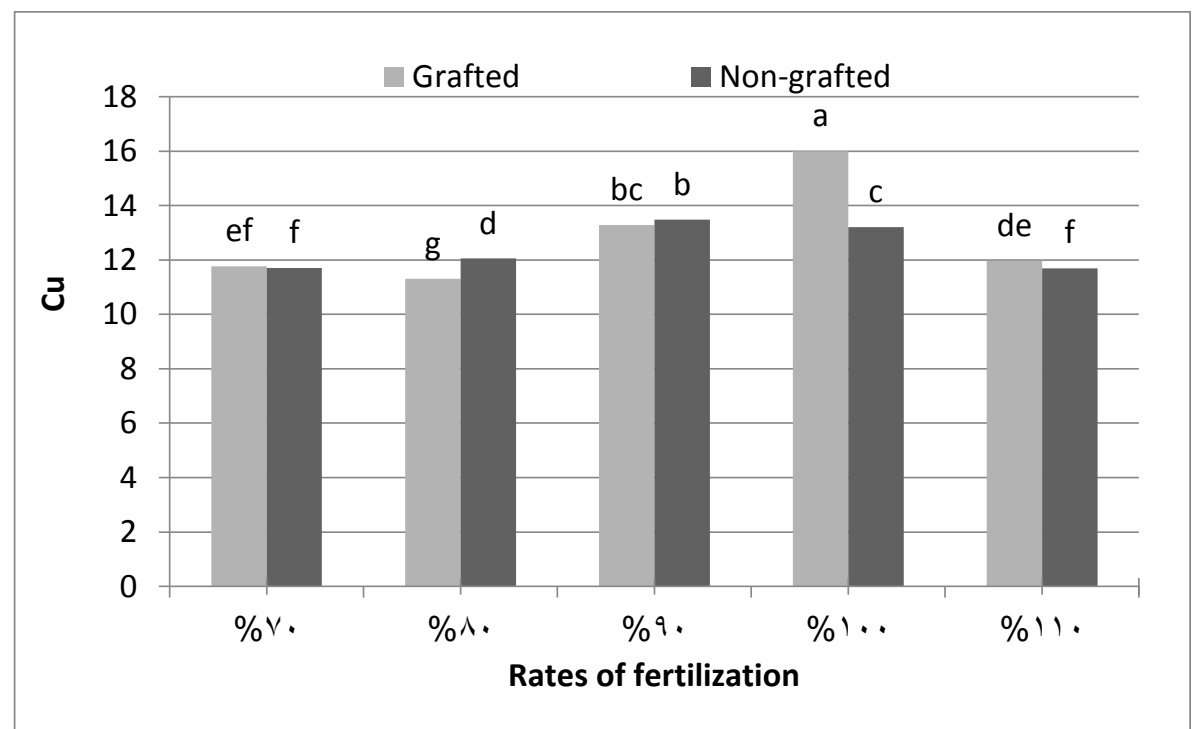

Figure 27: Effect of Nutrient Solution Strength on Copper of Cucumber Grown Hydroponically in greenhouse $1^{\text {st }}$ Season.

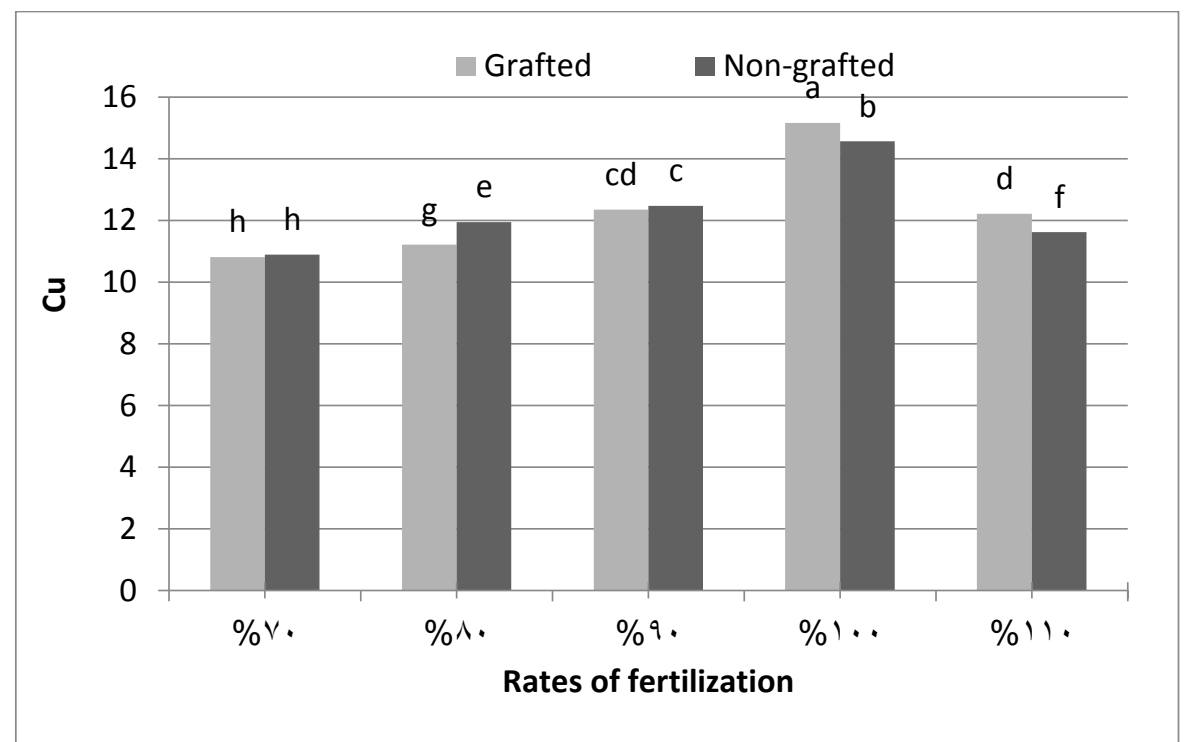

Figure 28: Effect of Nutrient Solution Strength on Copper of Cucumber Grown Hydroponically in greenhouse $2^{\text {nd }}$ Season.

\section{Fruit yield per plant}

Cucumber fruits are bound at the stem nodes, so the difference in fruit yield between plants according to treatments is due to the difference in nodes number, fruits number per node and individual fruit weight. The fruits number per node is governing genetically. Therefore, the difference between the plants or treatments in fruits yield is due to the difference in nodes number. As shown in (Figures 29 \& 30) the highest stem length and leaves number that reflecting the nodes number per plant stem was recorded in grafted plants and/or grown under $100 \%$ nutrient solution strength. These plants recorded the highest fruits yield per plant. On the other hand, Davis et al (2008a) stated that grafting 
M.E.M. Ahmed, et al.,

vegetables increase plant growth through water absorption, nutrients uptake and reform the hormonal balance, so improve fruit yield and quality. Even under stress condition grafting vegetables improve plant growth and yield and quality (Ropokis et al., 2019). The vigorous root system of the rootstock of cucumber can significantly absorb more water and nutrients consequently increase plant growth and yield even under less abundance the water and fertilizers, so maximize water and fertilizer use efficiency (Salehi-Mohammadi et al., 2009).

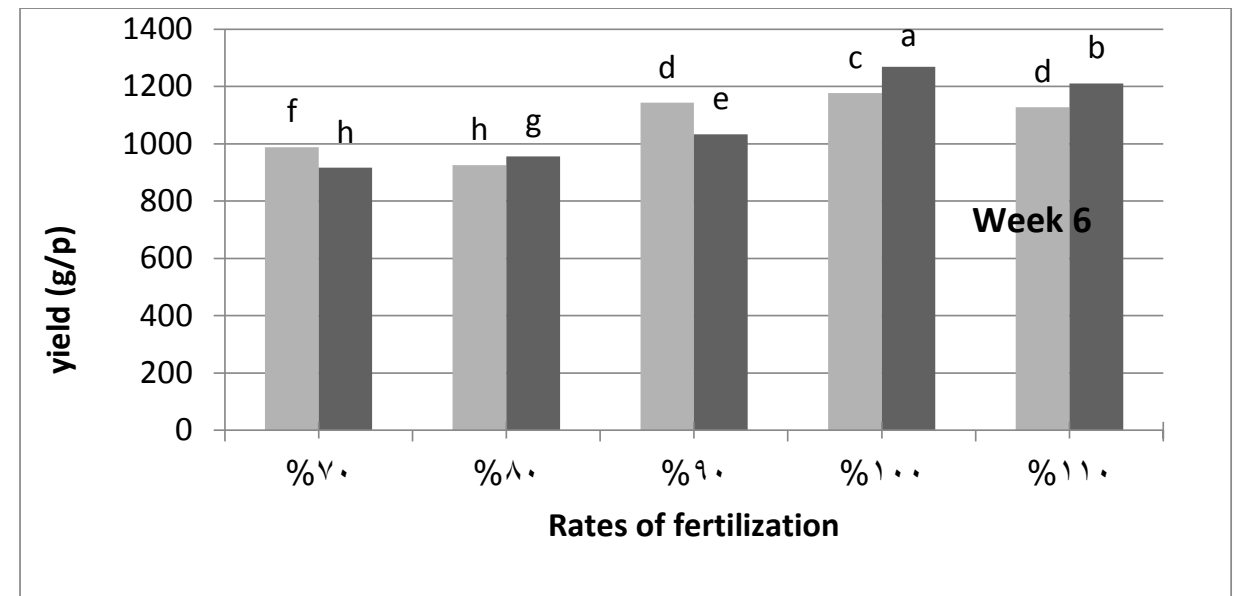

Figure 29: Effect of Nutrient Solution Strength on Fruits yield per plant of Cucumber Grown Hydroponically in greenhouse $1^{\text {st }}$ Season.

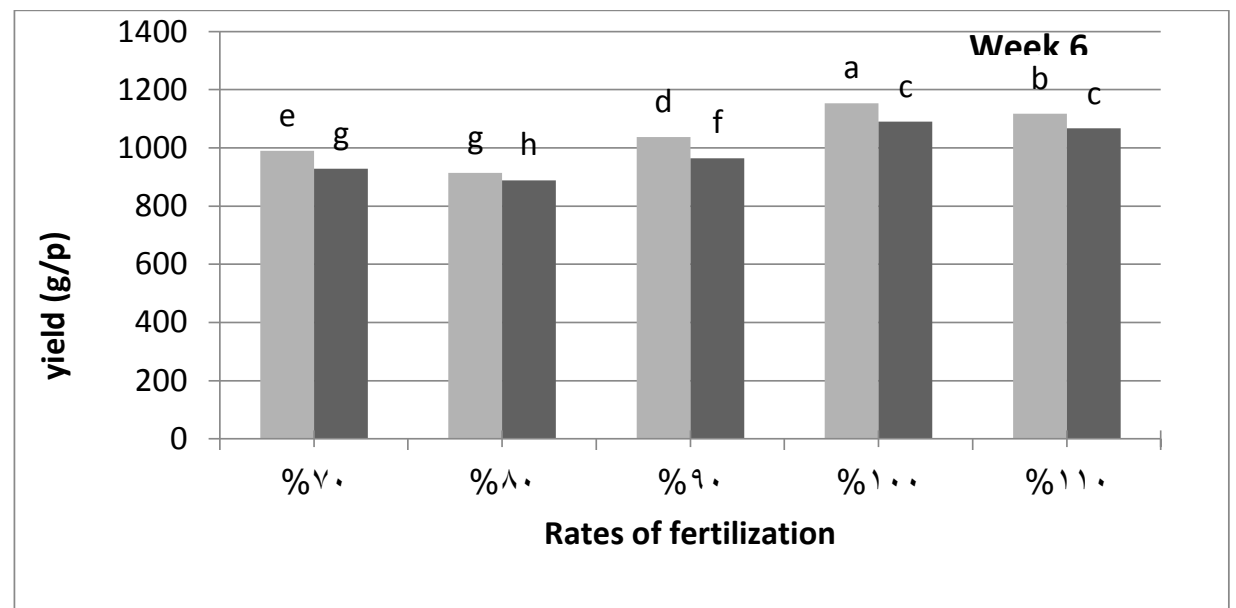

Figure 30: Effect of Nutrient Solution Strength on Fruits yield per plant of Cucumber Grown Hydroponically in greenhouse $2^{\text {nd }}$ Season.

\section{Conclusion}

Grafting globally is a routine practice to continue vegetables cultivation in the greenhouses to achieve agricultural intensification with minimal risks. The grafting is newly adopted as a propagation method for vegetables in
Egypt. Therefore, it is become necessary to determine greenhouses.

\section{REFERENCES}

A.O.A.C. (1985). Official Methods of Analysis of the Official the optimal margin of nutrient solution strength for grafted cucumber hydroponically 
in the Analytical Chemists.14 ed. Washington, D.C.

Bennett, W.F. (ed). (1993). Nutrient Deficiencies and Toxicities in Crop Plants. St. Paul, Minn. APS Press. 202 p.

Bogoescu, M., M. Doltu, B. lordache, M. Vintila, D. Sora and A. Mohora (2011). The Grafting Tomatoes Crop-an Alternative for Vegetable Growers. Bulletin UASVM Horticulture, 68: 215221

Bogoescui, M. and M. Doltuiei (2015). The Eggplants Crop Technology Optimization by Grafting. Bulletin UASVM Horticulture 72(2). DOI:10.15835/buasvmcn-hort:10314.

Cansev, A. and M. Ozgur (2010). Grafting cucumber seedlings on Cucurbita spp.: comparison of different grafting methods, scions and their performance. Journal of Food, Agriculture and Environment, 8 (3-4): 804-809

Davis, A.R., P.P. Veazie, H. Richard, A. Levis, S.R. King and X. Zhang (2008a). Grafting effects on vegetable quality. Hort Science, 43: 1670-1672.

Davis, A. R., P. Perkins-Veazie, Y. Sakata, S. L'opez-Galarza, J. V. Maroto, S.G. Lee, Y.C. Huh and Z. Sun (2008b). Grafting effects on vegetable quality. Hort Science, 43: 1670-1672.

El-Kersh, M. A. A., S. M. El-Meniawy and S. A. Abd El-Hady (2016). Grafting Can Modulate Watermelon Growth and Productivity under Egyptian Conditions.

Gregory, P.J., C.J. Atkinson, A.G. Bengough, M.A. Else, F. FernándezFernández, R.J. Harrison and S. Schmidt (2013). Contributions of roots and rootstocks to sustainable, intensified crop production. J Exp Bot.
64 (5):1209-22. doi: 10.1093/jxb/ers385. Epub 2013 Feb 1.

Huang, H. C., F. Kodama, K. Akashi and K. Konno (2002). Impact of Crop Rotation on Soilborne Diseases and Yield of Kidney Bean: A case study in northern Japan. Plant Pathol. Bull. 11: $75-84$.

Huang, Y., Z. Bie, S. He, B. Hua, A. Zhen and Z. Liu (2010). Improving cucumber tolerance to major nutrients induced salinity by grafting onto Cucurbita ficifolia. Environmental and Experimental Botany, 69: 32-38. http://dx.doi.org/10.1016/j.envexpbot.2 010.02.002

Jacobsen, J.S. and C.D. Jasper (1991). Diagnosis of Nutrient Deficiencies in Alfalfa and Wheat. EB 43, February 1991. Bozeman, Mont. Montana State University Extension. J. Plant Production, Mansoura Univ., Vol. 7 (9): 915 - 922,

Lee, J.M. and M. Oda (2003). Grafting of herbaceous vegetable and ornamental crops. Hort. Rev. (Amer. Soc. Hort. Sci.) 28:61-124.

Miguel, A., S. R. King, R. Cohen and J.M. Lee (2008b). Cucurbit grafting. Critical Reviews in Plant Sciences, 27:50-74, DOI: 10.1080/07352680802053940.

Nawaz, M. A., M. Imtiaz, Q. Kong, F. Cheng, W. Ahmed, Y. Huang and Z. Bie (2016). Grafting: A Technique to Modify Ion Accumulation in Horticultural Crops. Frontiers in plant science, 7, 1457. doi:10.3389/fpls.2016.01457

Ropokis, A., G. Ntatsi, C. Kittas, N. Katsoulas and D. Savvas (2019). Effects of Temperature and Grafting on Yield, Nutrient Uptake, andWater Use Efficiency of a Hydroponic Sweet Pepper Crop. Agronomy, 9 (2), 110; doi:10.3390/agronomy9020110. 
M.E.M. Ahmed, et al.,

Rouphael, Y., M. Cardarelli and G. Colla (2008). Yield, mineral composition, water relations, and water use efficiency of grafted mini-watermelon plants under deficit irrigation. Hortscience, 43(3):730-736.

Süß, A., M. Danner, C. Obster, M. Locherer, T. Hank and K. Richter
(2015). Measuring Leaf Chlorophyll Content with the Konica Minolta SPAD-502Plus - $\quad$ Theory, Measurement, Problems, Interpretation. EnMAP Field Guides Technical Report, GFZ Data Services. DOI:

http://doi.org/10.2312/enmap.2015.010.

تأثير قوة المحلول المغذى على نمو محصول الخيار المطعوم وغير المطعوم المزروع بنظام الهيدرويونيك في الصوب

محمد السيد محمد(') ، سلامه عبدالحميد عبدالهادى(r)، تامر محمد إبراهيم قنديل(") ، 
(1) رحاب محمد أبوإسماعيل محضى

(1) (1) قسم البساتين - كلية الزراعة - جامعة طنطا

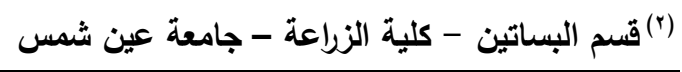
الملخص العربى البن

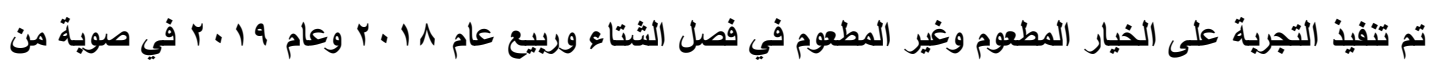

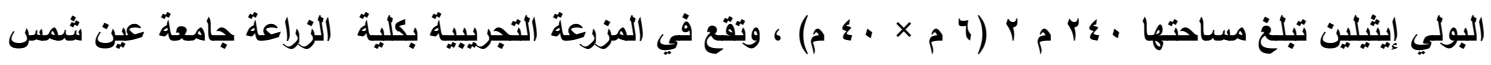

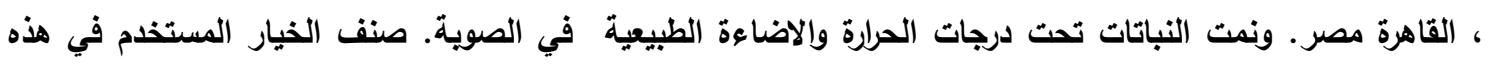

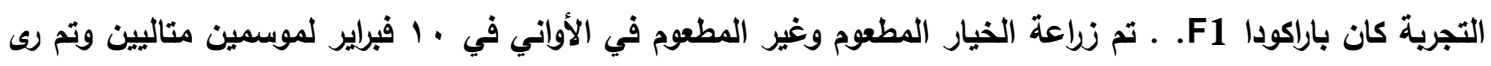

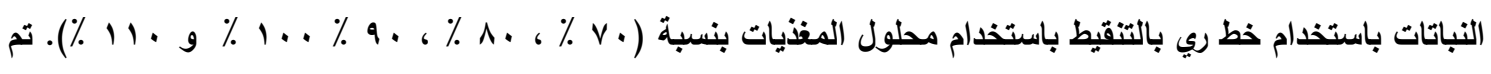

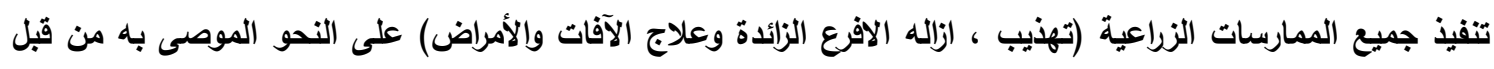

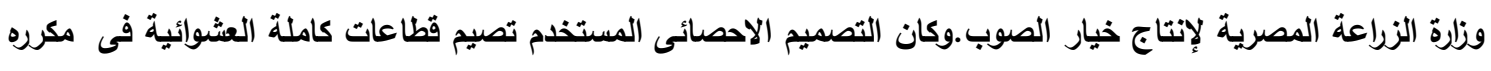

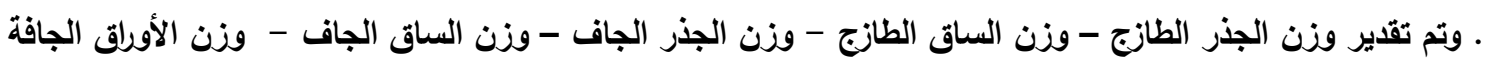

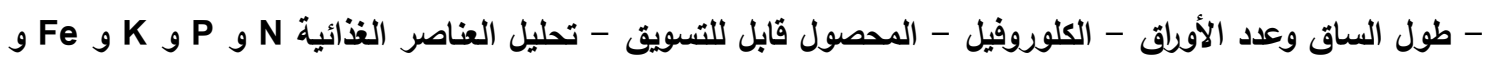

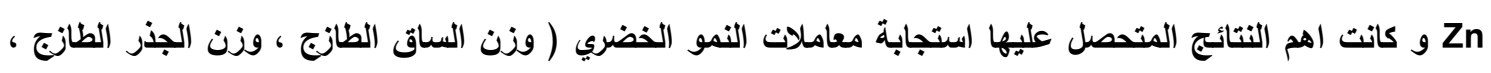

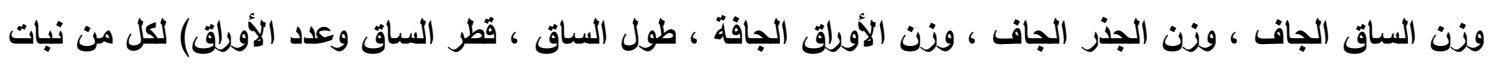

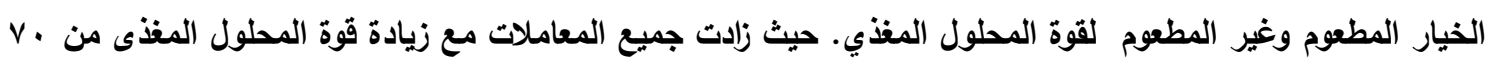

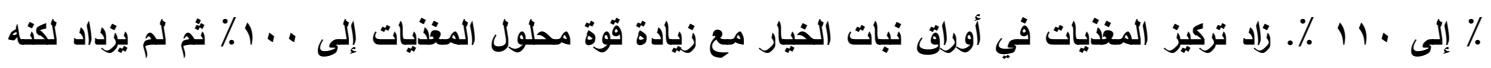

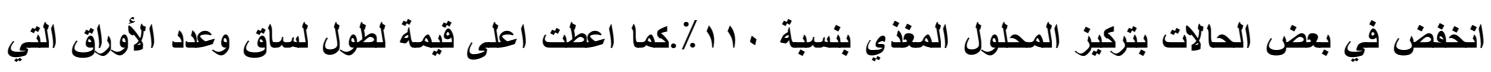

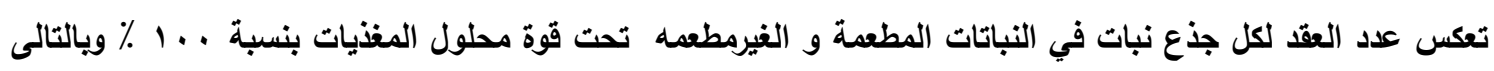

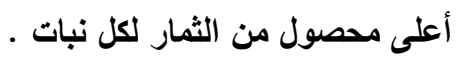

السادة المحكمين

أ.د / محمد محمد شاهين كلية الزراعة - جامعة القاهرة

أ.د/ نبيل محمد ملــش كلية الزراعة - جامعة المنوفية 